\title{
A Critical Look at the Physics Education Research in Turkey and in the World
}

\author{
Derya Kaltakçı Gürel*a, Nilüfer Didiş Körhasan ${ }^{\mathrm{b}}$
}

\begin{tabular}{l} 
Article Info \\
\hline DOI: $10.14686 /$ buefad.403625 \\
\hline Article History: \\
Received 09.03 .2018 \\
Accepted $\quad 09.06 .2018$ \\
Published $\quad 31.10 .2018$ \\
\hline Keywords: \\
Physics education, \\
Physics education research \\
topics, \\
Critical research. \\
\hline Article Type: \\
Research Article \\
\hline
\end{tabular}

\begin{abstract}
Physics education is an interdisciplinary research area, which was introduced first by physicists and has been researched for almost forty years. In this study, basic research areas in physics education, main journals published in this field, national and international congress and conferences, the pioneer physics education research groups in the world and their research areas were critically examined. The present study is a critical research study to find solutions to the questions of other researchers about the current status and recent trends in this field. In this respect, this study is conducted to enhance the students, who are registered undergraduate, graduate and doctoral programs of Science and Physics Education Majors of College of Education, to gain an overall idea about physics education research. In addition, by presenting theoretical and current trends, it aims to provide useful sources for physics educators in their research articles, thesis and projects.
\end{abstract}

\section{Türkiye'de ve Dünyada Fizik Eğitimi Araştırmalarına Kritik Bakış}

\begin{tabular}{|c|c|}
\hline \multicolumn{2}{|c|}{ Makale Bilgisi } \\
\hline \multicolumn{2}{|c|}{ DOI: $10.14686 /$ buefad. 403625} \\
\hline \multicolumn{2}{|c|}{ Makale Geçmişi: } \\
\hline Geliş & 09.03 .2018 \\
\hline Düzeltme & 09.06 .2018 \\
\hline Kabul & 31.10 .2018 \\
\hline \multicolumn{2}{|c|}{ Anahtar Kelimeler: } \\
\hline \multicolumn{2}{|c|}{ Fizik eğitimi, } \\
\hline \multicolumn{2}{|c|}{$\begin{array}{l}\text { Fizik eğitimi araştırma } \\
\text { alanları, }\end{array}$} \\
\hline \multicolumn{2}{|c|}{ Eleștirel araștırma. } \\
\hline \multicolumn{2}{|c|}{ Makale Türü: } \\
\hline \multicolumn{2}{|c|}{ Arastırma Makalesi } \\
\hline
\end{tabular}

\section{$\ddot{O} z$}

Fizik eğitimi, ilk olarak fizikçiler tarafından ortaya konulan ve yaklaşık son kırk yıldır çalışılan disiplinler arası bir araştırma alanıdır. $\mathrm{Bu}$ araştırmada, fizik eğitimi alanındaki temel çalışma alanları, bu alanda yayın yapan başlıca dergiler, ulusal ve uluslararası başlıca kongre ve konferanslar ile dünyada fizik eğitimi alanında çalışmalar yürüten gruplar ve bu grupların çalışma alanları irdelenmektedir. $\mathrm{Bu}$ çalışma, bu alanda çalışan araştırmacıların alanın mevcut durumu ve alandaki yönelimler ile ilgili sorularına cevap bulabilecekleri bir eleştirel araştırmadır. $\mathrm{Bu}$ bağlamda bu çalışma, Eğitim Fakültelerinin Fizik Eğitimi ya da Fen Eğitimi bölümlerinde lisans, yüksek lisans ve doktora programlarında öğrenim gören öğrencilerin fizik eğitimi alanına bütünsel bir bakış açısına sahip olmasını sağlamak amacıyla yapılmıştır. Araştırma aynı zamanda, fizik eğitimi araştırma alanının teorik ve güncel yapısını sunarak bu alanlarda bilimsel çalışmalar yapan akademisyenlerin makale, tez ya da projelerinde kaynak sağlamasını amaçlamaktadır.

\footnotetext{
*Corresponding Author: deryakaltakci@gmail.com

${ }^{a}$ Assist. Prof. Dr., Kocaeli University, Kocaeli/Turkey, https://orcid.org/0000-0003-3727-7516

bAssoc. Prof. Dr., Zonguldak Bülent Ecevit University, Zonguldak/Turkey, https://orcid.org/0000-0002-8108-1345
} 


\section{Introduction}

Starting from the 20th century, scientific and technological developments have brought new research fields and research topics. Physics education is one of those new research fields as a result of these developments. In recent years, many important studies were conducted in the field of physics education in Turkey and in the world. These studies not only strengthened physics education at all levels from primary school to university, but also revealed the fact that this area needs to be studied professionally. As a result, the number of master's and doctoral programs and the number of individuals studying in the field of physics education has been increasing day by day in our country (Kaltakçı Gürel, 2017).

Undoubtedly, as in other research areas, academic studies in physics education until today have spread to a wide range of areas. The present study aims to address the wide range of studies in the field of physics education by discussing basic studies in the literature with a holistic perspective.

The main aim of the study is to ensure the target audience to have a holistic perspective in the field and to lead the researchers in their thesis or research projects in this area. As well as giving an idea about the studies carried out to date in the field of physics education, this study aims to guide new researchers to the less studied areas and the areas that need more research. In short, the main purpose of this study is to reveal a Turkish source (please see the Turkish version of this article) to share the authors' knowledge acquired as a result of their both academic studies and their relations with physics education research groups ${ }^{1,2}$ abroad. Research questions focused in the present study are as follows:

1. What are the scope and trends of studies in the physics education field?

2. What are the main points that are criticized in physics education research?

3. What are the suggestions for changing and improving the current status of physics education research?

\section{Method}

This study is a critical research study which was conducted by two researchers in physics education in order to find solutions to the questions of other researchers about the current status and research trends in the field.

\section{Research Design}

A critical study is a research-based study on critical theories. It aims to figure out the existing disparities, activities and behaviors and to develop or change them by investigating the social and historical roots of the events (İzci, 2014). The main role of the researcher in a critical research is to provide solutions on how to improve and change the social community by critically inquiring it (Comstock, 1982).

Current research is composed of three main sections that are proposed by Alvesso and Deets (2000): insight, critique and transformation. Insight section involves in-depth understanding of the current status. In this section, the current status of physics education is intended to be understood in its historical context. With this aim, the current status of physics education research is presented to the reader with some descriptive data. In critique section, researchers interpret the current situation and criticize it. In fact, this part is the place where the studies in physics education are going to be criticized. Finally, in the transformation section, the solutions to the existing problems that were identified and criticized in insight and critique sections are discussed.

\section{Findings and Discussion}

In this part, the findings of the present study have been discussed separately in relation to the three main sections of a critical research.

\section{Insight into Physics Education Research Studies}

Being one of the basic disciplines of science, physics puts forward mathematical inferences, descriptions (laws) and explanations (theories) from micro to macro all about nature (Didiş, 2012). The origin of the first explanations about physics, which emerges as a result of the basic needs of mankind, dates back to the first civilizations. For example, the first people minimized the applied force to carry their load as a result of observing the nature by inventing the wheel. Thus, without being informed of the physics theories they had managed to use the facts or the laws of physics. Although in ancient times there were scientists like Archimedes and Ptolemy who were trying to 
describe physical phenomena with mathematics; Aristotle, who lived in $350 \mathrm{BC}$, was the first who developed insightful explanations (not descriptions) about physical phenomena such as force and motion (Halloun \& Hestenes, 1985a). Physics has continued its development and progress from prehistoric times to the present day based on the descriptions and explanations of the scientists working in this area. Yet, its progress is still ongoing today.

Although research in the field of physics is very old, scientific study in "physics learning and teaching" is relatively new. In 1957, Russia (former USSR) sent its first spacecraft called Sputnik into space. Afterwards, the developed countries like the United States (US) and the United Kingdom (UK) reconsidered the quality of their physics education programs. As a result, new curricula (such as PSSC physics), which were mainly based on inquiry and laboratory studies, were developed and physics concepts started to be taught at an earlier age. Although studies in physics education date back to the studies of John Dewey in the 1900s or to Jean Piaget's studies in the 1930s, [even some references (Meltzer \& Otero, 2015) accept high schools' and universities', such as MIT, transition to the laboratory experiments and inductive methods in physics courses in the $1860 \mathrm{~s}$ as a starting point], the foundations of physics education as a research field was laid by Robert Karplus (University of California Berkeley), Frederick Reif (University of California Berkeley) and Arnold Arons (University of Washington) in the 1960s. When it was realized that students do not learn what is taught in the 1970s, physics education studies started to be curriculum focused until 1990s and afterwards have increased dramatically in conceptual physics and high school physics (Meltzer \& Otero, 2015). Since then physics education research has become an important field due to its contribution to science (Cummings, 2011; McDermott, 2012; Meltzer \& Otero, 2015). The first studies of physics teaching curricula date back to 1934; then in 1935, 1938 and 1940 new physics teaching curricula was prepared (Göçen \& Kabaran, 2013). Afterwards, parallel to the global developments in the world, the Ministry of Education (ME) in Turkey had continued to the studies to improve the teaching of physics in secondary school education in 1960s. In Turkey, foundation of Course Instruments Construction and Repair Center in 1961, opening of Ankara Science High School as an implementer of modern science curricula (such as PSSC physics) in 1964, foundation of Science Education Development Scientific Commission in 1967 and working together with Scientific and Technological Research Council of Turkey (TUBITAK) to improve science programs coincided with this period. Although the curriculum development efforts in Turkey are in line with the ones in the world, the history of scientific research in the physics education field dates back to the 1990s (Sözbilir \& Canpolat, 2006). Prior to this year, very few scientific researches were observed. In 1997, with the reconstruction of the education faculties, physics education research in Turkey has gained a great impetus.

Physics education aims to identify students' problems in physics and develop some pedagogical tools and techniques to help students to understand physics at any grade level, from primary school to university (Didiş, 2012). Many students have problems with physics and they think that physics is a collection of facts and formulas; they cannot connect physics with daily life, and cannot solve physics problems (Hammer \& Elby, 2003). Although many of them get good grades, they have misconceptions, poor problem solving skills, and difficulty in interpreting physical laws (Reif, 1995). For these reasons, understanding the interrelationships among conceptual knowledge, mathematical skills and logical reasoning ability, will facilitate our knowledge to help students to be better problem solvers (Heron \& Meltzer, 2005). Similar to students' physics content knowledge; students' negative experiences, ideas, beliefs and expectations may be due to many different sources. However, as physics educators, we may start to convert these unfavorable situations to the favorable ones by revising physics instruction. For example, Redish and Steinberg (1999) explained the structure of the introductory physics courses as one of the reasons of student difficulties in physics. The approach of these courses is to explain many physics topics superficially to provide context for the later topics, as well as emphasizing mathematical operations and structures that are basis for the work at an advanced level. McDermott $(1991,1993,1997)$ emphasized that there is a mismatch between what teachers taught and what students learned. Many teachers have a tendency to see students as younger version of themselves, and are unaware of how students' perceptions and readiness result anxiety in learning physics.

According to the constructivist theory of teaching, students construct their new knowledge as a result of their interactions with the environment they live in and other individuals in this environment (Vygotsky, 1978). In doing so, they reconsider their old and existing knowledge and experiences. For this reason, to be informed about what students bring to the classroom is very important because it is interacting with new information presented in the class. Halloun and Hestenes (1985a, 1985b) and Hestenes, Wells and Swackhamer (1992) have mentioned about well-established intuitive beliefs systems as an important factor in student learning in physics. As a result, researchers have proposed the importance of consideration of preconceptions in teaching physics and the 
promotion of the conceptual understanding in an effective physics teaching (Dykstra, Boyle, \& Monarch, 1992). Researchers and research groups in physics education, like Lillian McDermott, performed various researches to identify student misconceptions on various physics topics. As a result of the identifications of difficulties, researchbased teaching materials were developed to promote conceptual learning. Force Concept Inventory (FCI) (Hestenes, Wells, \& Swackhamer, 1992), Mechanic Baseline Test (MBT) (Hestenes \& Wells, 1992), Force \& Motion Conceptual Evaluation (FMCE) (Thornton \& Sokoloff, 1998), Test of Understanding Graphs in Kinematics (TUG-K) (Beichner, 1994), Brief Electricity \& Magnetism Assessment Tool (BEMA) (Ding, Chabay, Sherwood, \& Beichner, 2006), Diagnosing and Interpreting Resistor Circuits (DIRECT) (Engelhardt \& Beichner, 2004), Light and Spectroscopy Concept Inventory (LSCI) (Bardar, Prather, Brecher, \& Slater, 2007), Four-Tier Geometrical Optics Test (FTGOT) (Kaltakci Gurel, Eryilmaz, \& McDermott, 2017), Mechanical Waves Conceptual Survey (Tongchai, Sharma, Johnston, Arayathanitkul, \& Soankwan, 2009), Three-Tier Heat and Temperature Test (Eryılmaz, 2010), Simple Electric Circuit Diagnostic Test (SECDT) (Peşman \& Eryılmaz, 2010), Electricity Concept Test (Aykutlu \& Şen, 2012) are some of the conceptual inventories used by physics education researchers in order to identify learning difficulties in some basic physics concepts. Kaltakci Gurel, Eryilmaz and McDermott (2015) listed other conceptual and multiple-tier tests used in physics education. Some of the research-based instructional materials developed to remedy learning difficulties and to enable conceptual learning are as follows (Beichner, 2009; McDermott, 2012; Rebello \& Zollman, 2005):

- Physics by Inquiry (McDermott, 1996) ${ }^{3}$ : It is an instructional material for pre- and in-service physics and science teachers that is based on learning by inquiry by hands on activities developed and implemented by Washington University Physics Education Researchers.

- Workshop Physics (Laws, 1991): This instructional material contains four learning modules. First, students were requested to predict about a physical event. Then, they observe the event and interpret it. If there is a discrepancy between their prediction and observation, students are requested to explain about it. Second, students develop definitions and mathematical theories based on their observations and predictions. Third, students try to verify their predictions based on a theory by conducting experiments. Last, students are requested to implement what they have learned to problem solving.

- Studio Physics (Wilson, 1994): It is a research based instructional program that students are in interaction with each other around tables in studio type classrooms and each table has computer based technology instead of classical lecture halls. It is an implementation of "Scale-Up" project development by Robert J. Beichner and his group at North Caroline State University.

- Socratic Dialog Laboratories (Hake, 1992): They are interactive laboratory activities developed in Indiana University that make students both physically and mentally active in introductory mechanics course.

- Interactive Lecture Demonstrations (Sokoloff \& Thornton, 1997): It is aimed to reveal students' previous knowledge and confront with that knowledge. The activities may be experiments or simulations.

- Modeling Physics (Wells, Hestenes, \& Swackhamer, 1995): It is an instructional program developed in Arizona State University to improve both high school and university level physics classes, and it aims to improve basic skills, mathematical modeling, and making inferences based on inquiry and collect and analysis of data by the help of technology.

- Peer Instruction (Mazur, 1997): It is an instructional methodology that aims to students' mentally participation to teaching process in crowded classes. The instructor divides lecture into parts (with 15 minutes) and try to reveal students' misconceptions by asking conceptual questions accompanying to the theoretical explanations. In this approach, it is aimed students' conceptual understanding with interaction of their peers.

- Tutorials in Physics (McDermott \& Shaffer, 1998): They are a research based instructional materials developed by Washington University for science and engineering departments and used in university level introductory physics classes (mechanics; electromagnetism; optics and waves). These materials especially prepared for the identification of common students' misconceptions and removal of them aim that supporting traditional lecturing and laboratory activities. 
- RealTime Physics and Microcomputer Based Laboratories-MBL (Sokoloff, Thornton, \& Laws, 1999): These materials aim students' drawing their motions graphs by means of microcomputers with sensors and allow students matching these graphs and their motions with simultaneous feedback.

Another important subject in physics education is organization of knowledge. Students do not always have consistent structures in their minds and try to explain physical phenomena by using these fragmented elements (phenomenological primitives: p-prims) (diSessa, 1983). Reif $(1995,1997)$ indicated the importance of knowledge organization and requirement of hierarchical knowledge organization in physics learning. He pointed out its reason that incoherent-disconnected knowledge did not provide a good basis for problem solving in physics. Although most of the students think that being a good physicist requires the memorization of many facts and formulas, it actually requires having an organized knowledge that permits remembering and inferring the details (Reif, 1995). Research focused on how knowledge organized by students in spite of the complex structure of student knowledge. By examining knowledge structures qualitatively and quantitatively, dynamic structure of students' thinking was tried to be modeled (Bao \& Redish, 2006; Borges \& Gilbert, 1999; Chiou \& Anderson, 2010; Corpuz \& Rebello, 2011; Didiş, Eryılmaz, \& Erkoç, 2014; Hrepic, Zollman, \& Rebello, 2010; Hubber, 2006; Itza-Ortiz, Rebello, \& Zollman, 2004; Özcan, 2015; Wittmann, Steinberg, \& Redish, 1999).

In addition to the cognitive studies on student learning, research in affective domain is also important. One of the issues that physics instructors should consider is the knowledge of students' awareness of their previous experiences and future expectations about physics. When students' expectations are identified, these expectations should be taken in consideration. Because these expectations play critical roles in the selection of activities while students are constructing their knowledge (Redish, Saul, \& Steinberg, 1998). In addition to the students' expectations, the other probable affective variables such as motivations, attitudes and beliefs were examined by physics educators and international questionnaires were developed. Some of these questionnaires are: EBAPSEpistemological Beliefs Assessment for Physical Science (White, Elby, Frederiksen, \& Schwarz, 1999), MPEXMaryland Physics Expectations Survey (Redish, Saul, \& Steinberg, 1998), CLASS-Colorado Learning Attitudes About Science Survey (Colorado Physics Education Research Group, 2004), VASS-Views About Sciences Survey (Halloun \& Hestenes, 1998). Most of the questionnaires about affective variables in physics education used in our country were translated from international questionnaires directly to Turkish (Aslan \& Taşar, 2013; YerdelenDamar, Elby, \& Eryılmaz, 2012). The difference of these adapted questionnaires (Azar, Şenler, \& Taşkın, 2006; Taşlıdere \& Eryılmaz, 2012) from the original ones is their physics content specific nature (i.e. specific for electricity, optics, mechanics, etc.)

Developments in computer-based technology also reflect on physics education research. Complex and expensive experiment setups such as Stern Gerlach provide physics educators and programmers develop simulations, animations, and multimedia about many physics concepts and use of them in instructions. Measurement of the influence of the technology on students' understanding of abstract concepts, scientific models, and relation of them with the real world is considerably difficult. For this reason, this research plays an important role on the development of the computer based instructional materials (Heron \& Meltzer, 2005).

Physics education is an interdisciplinary area since it is in interaction with many disciplines (Duit, Niedderer, $\&$ Schecker, 2007). These disciplines that physics education is directly in relation was presented in Figure 1.

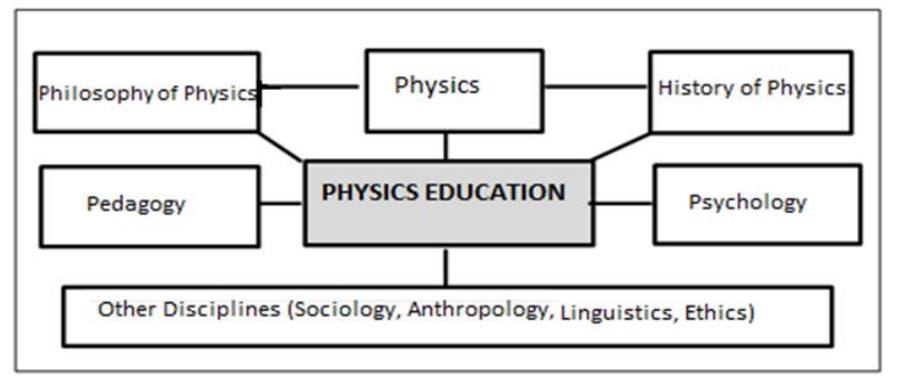

Figure 1. The Disciplines that Physics Education is Directly in Relation (Duit et al., 2007) 
As it is seen in Figure 1, physics education is in relation with many disciplines such as physics, psychology, pedagogy, etc. As the disciplines forming the nature of physics such as history of physics and philosophy of physics influenced physics, they also influence how to teach and learn physics. Pedagogy and psychology, which are the sub-disciplines of social sciences, are also the fundamental disciplines influencing physics education. These disciplines may be extended with mathematics, cognitive sciences, and educational sciences. As the interdisciplinary nature of physics education enriched the physics education research, the interpretation of the results by different disciplines provided an effective relationship among these disciplines. Another important point of interdisciplinary characteristics of physics education is the role of extending the findings to large number of audience. For this reason, many the findings about physics education research are published in the journals of different disciplines. Most of the research is published in physics, physics education, and science education and the results are shared with teachers. As similar with the world, the journals indexed and publishing physics education research exist in our country and number of these journals increases day by day. Due to the interdisciplinary nature of physics education, these journals can be educational sciences as well as physics journals published by journals of the natural sciences. Some of these journals are science education journals that generally reflect the interdisciplinary nature and some of them are physics education journals that more specifically reflect it. The journals publishing in this field - all physics and physics education journals, and science and educational science journals regarding their reputation in national and international literature - are listed and their publication frequencies were presented in Table 1.

Table 1. Primary Journals for Physics Education Research

\begin{tabular}{llcc}
\hline Name of Journal & $\begin{array}{c}\text { Publication } \\
\text { Frequency } \\
\text { (Yearly) }\end{array}$ & $\begin{array}{c}\text { National/ } \\
\text { International }\end{array}$ & Related Science Domain \\
\hline $\begin{array}{l}\text { Physical Review Special Topics-Physics } \\
\text { Education Research (PRST-PER) }\end{array}$ & 2 Issues & International & Physics Education \\
\hline The Physics Teacher (TPT) & 9 Issues & International & Physics Education \\
\hline Physics Education & 6 Issues & International & Physics Education \\
\hline Physics Education and Philosophy & 2 Issues & International & Physics Education \\
\hline European Journal of Physics (EJP) & 6 Issues & International & Physics \\
\hline American Journal of Physics (AJP) & 12 Issues & International & Physics \\
\hline Journal of Research in Science Teaching (JRST) & 10 Issues & International & Science Education \\
\hline Science Education & 6 Issues & International & Science Education \\
\hline Science \& Education & 10 Issues & International & Science Education \\
\hline International Journal of Science Education (IJSE) & 18 Issues & International & Science Education \\
\hline Research in Science Education (RISE) & 6 Issues & International & Science Education \\
\hline $\begin{array}{l}\text { International Journal of Science and Mathematics } \\
\text { Education }\end{array}$ & 6 Issues & International & $\begin{array}{c}\text { Science and Mathematics } \\
\text { Education }\end{array}$ \\
\hline $\begin{array}{l}\text { Eurasia Journal of Mathematics, Science and } \\
\text { Technology Education (EJMSTE) }\end{array}$ & 6 Issues & International & $\begin{array}{c}\text { Science and Mathematics } \\
\text { Education }\end{array}$ \\
\hline Journal of Turkish Science Education (TUSED) & 4 Issues & National & Science Education \\
\hline Hacettepe University Journal of Education & 4 Issues & International & Educational Sciences \\
\hline Education and Science & 4 Issues & International & Educational Sciences \\
\hline Eurasian Journal of Educational Research (EJER) & 4 Issues & International & Educational Sciences \\
\hline Educational Sciences: Theory \& Practice (ESTP) & 6 Issues & International & Educational Sciences \\
\hline
\end{tabular}

Success in academic knowledge and affective variables obtained by the implementation of research based instructional methodologies facilitated pursuing doctoral research in that area and more financial support from the government budget to research. By this way number of physics education research groups in the physics departments of prestigious universities in US increased (Heron \& Meltzer, 2005; McDermott, 2012). In our country, physics education research is conducted at universities locally and independent of each other; however, increase in physics education doctoral studies and financial support by government for research are parallel with US. The content analysis studies that have been carried out on graduate theses (Kaltakçı-Gürel et al., 2017a), articles published in peer-reviewed journals (Kaltakçı-Gürel et al., 2017b; Önder et al., 2014) and contributions in national congress (Kanlı et al., 2014) in the field of physics education in our country reveal this situation. However, although the increase in the number of government support and the increase in the number of researchers are 
similar, in the world physics education is studied in the central research groups focusing on specific research topics, including researchers from different disciplines, while in our country, this situation continues interactively by collaborations of researchers at the relevant departments in the faculty of education. Table 2 presents the primary physics education research groups all over the world.

Table 2. Leading Physics Education Research Groups

\begin{tabular}{|c|c|c|c|}
\hline Group Name & University & $\begin{array}{l}\text { Primary Research } \\
\text { Area }\end{array}$ & Leading Researchers \\
\hline PEG & Washington University, USA & Physics by inquiry & $\begin{array}{l}\text { Lillian C. McDermott } \\
\text { Paula Heron }\end{array}$ \\
\hline UMDPERG & Maryland University, USA & $\begin{array}{l}\text { Mental models, } \\
\text { Epistemology, } \\
\text { MPEX }\end{array}$ & Joe Redish \\
\hline K-SUPER & Kansas State University, USA & Mental models & Dean Zollman \\
\hline PER@C & $\begin{array}{l}\text { University of Colorado } \\
\text { Boulder, USA }\end{array}$ & $\begin{array}{l}\text { Interactive physics } \\
\text { Simulations, } \\
\text { Improvement of advance } \\
\text { physics classes, } \\
\text { CLASS }\end{array}$ & $\begin{array}{l}\text { Steven Pollock } \\
\text { Noah Finkelstein } \\
\text { Valerie Otero }\end{array}$ \\
\hline Mazur Group & Harvard University, USA & Peer Instruction & Eric Mazur \\
\hline ASU-PER & $\begin{array}{l}\text { Arizona State University, } \\
\text { USA }\end{array}$ & $\begin{array}{l}\text { Modeling, } \\
\text { Physics teacher education }\end{array}$ & $\begin{array}{l}\text { David Hestenes } \\
\text { David Meltzer }\end{array}$ \\
\hline PERL & Maine University, USA & Activity based physics & $\begin{array}{l}\text { Michael C. Wittman } \\
\text { MacKenzie R. Stetzer }\end{array}$ \\
\hline SESAME & $\begin{array}{l}\text { University of California } \\
\text { Berkeley, USA }\end{array}$ & Epistemology & Andrea diSessa \\
\hline PER & Dickinson College, USA & Workshop physics & Priscilla Laws \\
\hline PER & $\begin{array}{l}\text { University of Minnesota, } \\
\text { USA }\end{array}$ & Context rich problems & $\begin{array}{l}\text { Patricia Heller } \\
\text { Kenneth Heller (retired) }\end{array}$ \\
\hline CRMSE & $\begin{array}{l}\text { San Diego State University, } \\
\text { USA }\end{array}$ & $\begin{array}{l}\text { Physics and everyday } \\
\text { thinking (PET) }\end{array}$ & Fred Goldberg \\
\hline SUPER & Sydney University, Australia & $\begin{array}{l}\text { Conceptual physics } \\
\text { teaching and concept tests, } \\
\text { Multimedia }\end{array}$ & Manjula Sharma \\
\hline $\begin{array}{l}\text { Department of Science } \\
\text { Teaching }\end{array}$ & $\begin{array}{l}\text { Weizmann Institute of } \\
\text { Science, Israel }\end{array}$ & $\begin{array}{l}\text { Conceptual physics } \\
\text { teaching, } \\
\text { Teacher education }\end{array}$ & Bet-Sheva Eylon \\
\hline $\begin{array}{l}\text { URDF (Research Unit } \\
\text { for Physics Education) } \\
\text { CLDF (Laboratory } \\
\text { Center for Physics } \\
\text { Education) }\end{array}$ & Udine University, Italy & $\begin{array}{l}\text { Physics teacher education, } \\
\text { Mental models }\end{array}$ & Marisa Michelini \\
\hline $\begin{array}{l}\text { The Division of Physics } \\
\text { Education }\end{array}$ & Uppsala University, Sweden & $\begin{array}{l}\text { Higher education, } \\
\text { Scientific literacy }\end{array}$ & Cedric Linder \\
\hline $\begin{array}{l}\text { Physics Teacher } \\
\text { Education }\end{array}$ & $\begin{array}{l}\text { Helsinki University, } \\
\text { Finland }\end{array}$ & Physics teacher education & Ismo Koponen \\
\hline
\end{tabular}

In Table 2, the physics education research groups leading physics education research were summarized. Although these research groups were mainly in US, other research groups outside of US are expected to be increased. International collaborations with these research groups will play important role in the increase. By considering this issue for our country, physics education researchers who got their doctoral degree from other countries go back to Turkey and have academic positions in the universities. In addition, the researchers having academic research and social experience abroad during doctoral research by government support will increase the number of physics education research and it will provide more comprehensive and comparative research with international research groups. One of the important points for national and international collaborations is the 
presentation of physics education research findings in the conferences that many researchers meet. Many national and international congress and conferences in physics education research are organized and opportunities are given to physics educators for knowledge exchange. These organizations can be categorized under two themes, physics and science education, as similar with the physics education research. Table 3 presents the main congresses and conferences and their meeting frequencies.

Table 3. National and International Activities for Physics Education Research

\begin{tabular}{|c|c|c|c|}
\hline Name of Activity & $\begin{array}{c}\text { Meeting } \\
\text { Frequency }\end{array}$ & $\begin{array}{c}\text { National/ } \\
\text { International }\end{array}$ & Related Science Domain \\
\hline $\begin{array}{l}\text { Physics Education Research Conference } \\
\text { (PERC) }\end{array}$ & Yearly & International & Physics Education \\
\hline $\begin{array}{l}\text { American Association of Physics Teachers } \\
\text { (AAPT) }\end{array}$ & Twice per year & International & Physics Education \\
\hline $\begin{array}{l}\text { International Conference on Physics Education } \\
\text { (ICPE) }\end{array}$ & $\begin{array}{l}\text { Yearly or every } \\
\text { two years }\end{array}$ & International & Physics Education \\
\hline $\begin{array}{l}\text { The International Research Group on Physics } \\
\text { Teaching (GIREP) }\end{array}$ & Yearly & International & Physics Education \\
\hline $\begin{array}{l}\text { Multimedia in Physics Teaching and Learning } \\
\text { (MPTL) }\end{array}$ & Yearly & International & Physics Education \\
\hline $\begin{array}{l}\text { Physics Teacher Education Coalition } \\
\text { Conference (PTEC) }\end{array}$ & Yearly & International & Physics Education \\
\hline $\begin{array}{l}\text { Physics Teaching in Engineering Education } \\
\text { Conference (PTEE) }\end{array}$ & $\begin{array}{l}\text { Every two or } \\
\text { three years }\end{array}$ & International & Physics Education \\
\hline Gordon Research Conferences (GRC) & Yearly & International & Physics Education \\
\hline National Physics Education Congress (UFEK) & Every two years & National & Physics Education \\
\hline $\begin{array}{l}\text { Turkish Physical Society International Physics } \\
\text { Congress (TFD) }\end{array}$ & Yearly & International & Physics \\
\hline American Physical Society Meeting (APS) & $\begin{array}{l}\text { More than once a } \\
\text { year }\end{array}$ & International & Physics \\
\hline $\begin{array}{l}\text { International Physics Conference of the Balkan } \\
\text { Physical Union (BPU) }\end{array}$ & Every three years & International & Physics \\
\hline $\begin{array}{l}\text { National Association for Research in Science } \\
\text { Teaching (NARST) }\end{array}$ & Yearly & International & Science Education \\
\hline $\begin{array}{l}\text { European Science Education Research } \\
\text { Association (ESERA) }\end{array}$ & Every two years & International & Science Education \\
\hline $\begin{array}{l}\text { The International Organization for Science and } \\
\text { Technology Education Symposium (IOSTE) }\end{array}$ & Yearly & International & Science Education \\
\hline $\begin{array}{l}\text { International Society of Educational Research } \\
\text { (ISER) }\end{array}$ & Yearly & International & $\begin{array}{l}\text { Science and Mathematics } \\
\text { Education }\end{array}$ \\
\hline $\begin{array}{l}\text { Frontiers in Mathematics and Science } \\
\text { Education Research Conference (FISER) }\end{array}$ & Every five years & International & $\begin{array}{l}\text { Science and Mathematics } \\
\text { Education }\end{array}$ \\
\hline $\begin{array}{l}\text { National Science and Mathematics Education } \\
\text { Congress (UFBMEK) }\end{array}$ & Every two years & National & $\begin{array}{l}\text { Science and Mathematics } \\
\text { Education }\end{array}$ \\
\hline
\end{tabular}

In addition to these congress and conferences, the research results in physics education are discussed in many national and international congress and conferences about educational sciences. Especially in recent years, as well as the number of national and international scientific activities in education held in our country, there is an increase in the number of scientific activities focused on science and physics education and the number of the participants doing research in physics education in these activities.

\section{Critiques about Physics Education Research}

Physics education research is conducted in physics departments and education faculties unlike chemistry and biology. In US, it became a research area in physics departments. For this reason, in physics teaching and learning research, physics departments have important roles (Heron \& Meltzer, 2005). Although some pioneers of the physics education such as Lillian McDermott do not have the same idea with, Joe Redish and Fred Reif consider one of the biggest problem in physics education research by physics departments in US is that lack of discussion of theoretical issues (Cummings, 2011; Redish, 1994). If it is not considered the studies about pre and 942 
misconceptions about different physics concepts from 1970s to now, theoretical frameworks of the physics education research by research groups in physics departments for a long time is limited (Redish, 1994); however, physics education research presented by science educators have deep and long established theoretical framework. Especially, by using the advanced statistics and research methodologies the generalization and repetition of research results were increased. However, physics education research conducted in physics departments made great contributions to the science educators in terms of discussed physics concepts, developed instructional methodologies and materials and implementation areas and they still continue to contribute.

In our country, conduction of physics education research studies is different from US. That means, in our country, physics education research is conducted at faculty of educations as similar with common in Europe and very limited in US. This situation causes differences in research and implementation of research results in daily life. Some part of physics education research is conducted by collaboration with physics departments and students' learning of upper level physics concepts is examined. At this time, although the findings make direct contributions to the literature, implementation of new knowledge and findings in practically is a bit limited. That means, while the research groups in US and similar research groups at physics departments reflect the findings into the physics teaching and improve physics classes, it is very limited in our country. The findings of research conducted by faculties of education reflected mostly on the secondary physics curriculum and physics teacher education course content and they have local contributions in practical implementations. These can be both improvement of the preservice teacher's subject matter knowledge (physics knowledge) and pedagogy knowledge (the use of physics knowledge in physics teaching). It is expected that the increase of collaborative research between physics departments and education faculties after the physics education research widened and gained importance. One of the best examples for this situation is the curriculum development period for science and technology and secondary physics in our country. In the curriculum development period, in addition to other research areas (chemistry, mathematics, psychology etc.) researchers from both physics and physics education worked together and produced a curriculum with theoretically strong and limited problems about physics concepts.

Another critique is the lack of physics education research groups in our country and then conduction of most research is individually. There are 13 secondary science physics education departments in the faculties of education and there are doctoral programs for physics education. In addition, there are faculty members studying physics education, master's and doctoral students in most of the universities' science education departments. In contrast, physics education studies are independent of each other, with small budget and the product of individual research. It is expected that the emerging of physics education research groups with the increase of physics educators in and out of the country who completed their work.

\section{Conclusion: Transformation of Physics Education Research}

The physics education research starting in 1970s has focused on students' skills for using concepts (i.e. mechanics and electricity) in introductory physics classes and it has valuable roles in the development of physics instructions at first. Nowadays, the research was enlarged with including the studies about kinematics, electromagnetism and modern physics (Heron \& Meltzer, 2005). Finally, recent research focuses on how students learn of upper level physics concepts such as thermodynamics, optics, relativity, and quantum physics. The physics education research accelerated in last 25 years in our country basically focuses on the basic physics concepts with the lack of interaction between physics and physics departments. Existent body of research is especially in elementary, secondary and teacher education (in or pre) levels. However, the scope of physics education research should be extended from primary education to university level (science and engineering etc.), even to adult education (academics and parents etc.). By this way, the goals as being scientifically literate society are obtained.

National and international content analysis studies in physics education (Kaltakçı-Gürel et al., 2017a; Kaltakç1Gürel et al., 2017b; Kanlı et al., 2014; Önder et al., 2013) and science education (Chang, Chang, \& Tsang, 2010; Lee, Wu, \& Tsai, 2009; Tsai \& Wen, 2005; Tzu-Chiang, Tzung-Jin, \& Chin-Chung, 2014) make an important contribution to the literature by showing the gaps and shortcomings in the field. While Önder et al. (2013) identified 'Learning approaches' and 'Misconceptions/learning difficulties' as the mostly studies themes by examining 46 physics education research articles in Journal of Turkish Science Education (TUSED) between the years 2004 and 2011 by content analysis, Kanlı et al. (2014) found that the 'Nature of physics', 'Epistemology and Science literacy', 'Modeling' and 'Gifted education' were the least studied themes as a result of their content analysis study on 282 physics education studies presented and published in National Science and Mathematics Education Congress between the years 1994-2012. In international content analysis studies in science education 
(Chang et al., 2010; Lee et al., 2009; Tzu-Chiang et al., 2014) field, 'Conceptual change' and 'Conceptions / Misconceptions' were found to be the most featured themes, while 'Informal learning' and 'Educational technology' were the least studied themes. The number and diversity of research methodologies and strategies, instructional methodologies, and development and adaptation of instruments in physics education increase day by day. It is a motivating progress and the research in physics education -conducted and still need to be researchedcan be summarized as follows: Identification of preconceptions and misconceptions, organization of knowledge: mental models, conceptual change, curriculum development studies in physics education, physics teacher education and physics teacher competencies, history and nature of physics, technology in physics education, laboratory experiences and inquiry based learning in physics, problem solving and problem based learning in physics, context based physics learning, effect of affective variables (motivation, attitude etc.) on physics learning, and physics education for gifted students.

While physics education research group in the different universities of world or research centers are specializing in a specific research area and in collaboration with each other with great projects with great success, it is thought that similar approaches should be considered in our country.

In conclusion, physics education research progressed up to now and became a separate discipline in the literature. As physics educators, we should make effort to improve it more. We believe that this study will answer the questions about what physics education is or not and will guide and lighten the new researchers in physics education. This study criticizing the physics education research in our country and over the world is a Turkish (please see the Turkish version of this article) resource for the master's and doctoral students in physics education.

\section{Acknowledgement}

${ }^{1}$ Experience of the first author at the University of Washington (WA), Physics Education Group (PEG), supervised by Prof. Dr. Lillian C. McDermott.

${ }^{2}$ Experience of the second author at the University Maryland (MD), Physics Education Research Group (UMDPERG), supervised by Prof. Dr. Edward F. (Joe) Redish, and at the Harvard University (MA), Physics/Education Research Group (Mazur Group), supervised by Prof. Dr. Eric Mazur.

${ }^{3}$ It started to be used in 1977 first, but the book was published in 1996 (McDermott, 2012). 


\section{Türkiye'de ve Dünyada Fizik Eğitimi Araştırmalarına Kritik Bakış}

\section{Giriş}

20. yüzyıldan günümüze hızla değişen ve gelişen bilimsel ve teknolojik olgular, beraberinde yeni araştırma alanları ve araştırma konularını getirmiştir. Fizik eğitimi araştırmaları da, bu geliş̧meler neticesinde öne çıkan yeni araştırma alanları arasında yer almaktadır. Türkiye ve dünyada fizik eğitimi alanında özellikle son yıllarda birçok etkili çalışma yapılmıştır. Bu çalı̧̧alar bir yandan ilköğretimden üniversiteye her kademede fizik öğretimini güçlendirdiği gibi, diğer yandan bu alanın profesyonel anlamda üzerinde hassaslıkla çalışılması gereken bir alan olduğu gerçeğini ortaya çıkarmıştır. Bunun neticesinde ülkemizde, fizik eğitimi alanında yüksek lisans ve doktora programlarının sayısı ve bu alanda çalışan bireylerin sayısı her geçen gün biraz daha artmaktadır (Kaltakçı Gürel, 2017).

Hiç şüphesiz bilimin diğer alanlarında olduğu gibi, fizik eğitimi alanında da günümüze kadar yapılan akademik çalışmalar geniş bir yelpazeye yayılmıştır. Bu araştırma fizik eğitimi alanında yapılan temel çalışmaları ele alıp literatürde yer alan bu geniş yelpazedeki çalışmalara değinmeyi amaçlamaktadır.

$\mathrm{Bu}$ araştırma, okuyucuların fizik eğitimi alanında bütünsel bir bakış açısına sahip olmalarını sağlamak; makale, tez ya da projelerinde bu alanda çalışma yapacak araştırmacılara önderlik etmesi amacıyla hazırlanmıştır Fizik eğitimi alanında çalışmaya başlayacak yeni araştırmacılara alanda günümüze kadar yapılan çalışmalar hakkında fikir vermesinin yanı sıra bu alanlarda az çalışılan ve daha fazla araştırmayı gerektiren noktalara dikkat çekerek araştırmacıları çalışma alanları açısından yönlendirmeyi amaçlamaktadır. Kısaca, bu araştırmanın temel amacı, yazarların gerek akademik çalışmaları gerekse yurtdışındaki fizik eğitimi araştırma gruplarıyla ${ }^{1,2}$ olan ilişkileri neticesindeki edindikleri bilgi ve deneyimlerini Türkiye'deki araştırmacılarla paylaşacakları Türkçe bir kaynak ortaya koymaktır. Çalışmada odaklanılan başlıca araştırma soruları şu şekildedir:

1. Fizik eğitimi alanındaki temel çalışmaların kapsamı ve yönelimleri nelerdir?

2. Fizik eğitimi çalışmalarında kritik edilen temel noktalar nelerdir?

3. Fizik eğitiminin mevcut durumunun değiştirilip geliştirilmesi için çözüm önerileri nelerdir?

\section{Yöntem}

$\mathrm{Bu}$ çalışma, fizik eğitimi alanında çalışan iki araştırmacının bir araya gelerek bu alanda çalışan diğer araştırmacıların alanın mevcut durumu ve alandaki yönelimler ile ilgili sorularına cevap bulabilmek için yürütmüş olduğu bir eleştirel araştırmadır.

\section{Araştırma Modeli}

Eleştirel araştırma, eleştirel kuramı temel alan ve olayların sosyal ve tarihsel köklerini inceleyerek mevcut dengesizlikleri, eylemleri, davranışları anlamayı ve değiştirip geliştirmeyi hedefleyen bir araştırma yöntemidir (İzci, 2014). Bir eleştirel araştırmada araştırmacının en büyük rolü içinde bulunduğu sosyal yapıyı eleştirel bir gözle sorgulayarak nasıl değiştirilip geliştirileceği hakkında çözüm önerileri sunmasıdır (Comstock, 1982).

Araştırma, Alvesson ve Deets (2000) tarafindan belirtilen ve bir eleştirel araştırmada bulunması gereken üç temel unsur olan derinlemesine bakış (insight), eleştiri (critique) ve dönüşümün (transformation) ele alındığı üç temel bölümden meydana gelmektedir. Derinlemesine bakış bölümü mevcut durumun anlaşılmasını içerir. $\mathrm{Bu}$ bölümde tarihsel çerçevede ele alınan fizik eğitiminin mevcut durumu ortaya koyularak anlaşılması amaçlanır. $\mathrm{Bu}$ amaçla, bu bölümde fizik eğitimi araştırmalarına ait mevcut durum betimsel verilerle okuyuculara sunulur. Eleştiri bölümünde, araştırmacılar mevcut durumu yorumlayıp kritik bir gözle eleştirir. Yani bu bölüm fizik eğitimi alanındaki araştırmaların kritik edileceği bölümdür. Dönüşüm bölümünde ise, derinlemesine bakış ve eleştiri bölümlerinde fizik eğitimi alanında tespit edilip kritik edilen mevcut sorunlara getirilen çözümler tartışılır.

\section{Bulgular ve Tartışma}

Bu bölümde, çalışmanın bulguları eleştirel araştırmanın üç temel bölümüne uygun başlıklar altında ayrı ayrı ele alınarak tartışılmıştır.

\section{Fizik Eğitimi Çalışmalarına Derinlemesine Bakış}

Bilimin temel disiplinlerinden birisi olan fizik; mikrodan makroya, canlıdan cansıza tüm doğa hakkında matematiksel çıkarımlar, tanımlamalar (yasalar) ve açıklamalar (teoriler) ortaya koyar (Didiş, 2012). İnsanoğlunun 
temel gereksinimlerinin sonucu ihtiyaç duyulan fizik ile ilgili ilk açıklamaların kökeni dünyada kurulan ilk uygarlıklara kadar uzanır. Mesela, ilk insanlar doğayı gözlemlemeleri sonucu ve ihtiyaçları doğrultusunda tekerleği icat ederek, yüklerini taşımak için uygulayacakları kuvveti en aza indirmişlerdir. Böylece fiziğin teori veya yasalarından haberdar olmadan fiziğin olgularını kullanabilmeyi başarmışlardır. Antik çağlarda Arşimet (Archimedes) ve Batlamyus (Ptolemy) gibi fiziksel olguları matematiksel olarak tanımlamaya çalışan bilim insanları olsa da, milattan önce 350'lerde yaşayan Aristoteles, kuvvet ve hareket gibi fiziksel olgular hakkında sezgilere dayalı açıklamalar geliştiren (tanımlamalar değil) ilk kişi olmuştur (Halloun \& Hestenes, 1985a). Tarih öncesi çağlardan günümüze fizik bilimi, bu alanda çalışan bilim insanlarının tanımlama ve açıklamalarına dayanarak büyük bir ilerleme kaydederek gelişimini sürdürmüş ve bu gelişim günümüzde hala sürmektedir.

Fizik alanında yapılan araştırmalar ve bilimsel açıklamalar çok eskiye uzanırken "fizik öğrenme ve öğretmeye" dair bilimsel çalışmaların nispeten çok yeni olduğunu görebiliriz. 1957'de Rusya'nın (eski SSCB) uzaya Sputnik isimli ilk uzay aracını göndermesi, Amerika Birleşik Devletleri (ABD) ve İngiltere gibi diğer gelişmiş ülkelerin fizik öğretimlerinin kalitesini tekrar gözden geçirmelerine ihtiyaç oluşturmuş̧ur. Bunun neticesinde yeni öğretim programları (PSSC fiziği gibi) oluşturulmuş, araştırmaya ve laboratuvar çalışmalarına dayalı bir fizik öğretimi öne çıkmış ve fizik kavramlarının daha erken yaşlarda öğretilmeye başlanmasına yol açmışıı. Fizik eğitimi alanındaki çalışmalar 1900'lerde John Dewey veya 1930'larda Jean Piaget'nin çalışmalarına kadar dayandırılsa da [hatta bazı kaynaklar (Meltzer \& Otero, 2015) 1860'larda liselerin ve Massachusetts Teknoloji Enstitüsü (MIT) gibi bazı üniversitelerin fizik derslerinde laboratuvar deneylerine ve tümevarım metotlarına geçişini başlangıç kabul eder], bir araştırma alanı olarak fizik eğitimi ile ilgili bilimsel araştırmaların temeli 1960'larda Robert Karplus (California Üniversitesi Berkeley), Frederick Reif (California Üniversitesi Berkeley) ve Arnold Arons'un (Washington Üniversitesi) çalışmalarıyla atılmıştır. Fakat 1970'lerde öğrencilerin öğretilenleri tam olarak öğrenmediğinin fark edilmesiyle fizik eğitimi alanındaki araştırmalar 90'lı yıllara kadar müfredat çalışmaları odaklı, sonrasında ise kavramsal fizik ve lise fiziği çalışmaları ile (Meltzer \& Otero, 2015) ciddi şekilde artmıştır. Belirtilen tarihlerden bu yana ise bilime olan katkılarından ötürü gün geçtikçe önemi daha iyi anlaşılan bir araştırma alanı haline gelmiştir (Cummings, 2011; McDermott, 2012; Meltzer \& Otero, 2015). Türkiye'de fizik öğretim programlarıyla ilgili ilk çalışmalar 1934 yılına uzanmakta, 1935, 1938 ve 1940 yıllarında fizik öğretim programları hazırlan dığı görülmektedir (Göçen \& Kabaran, 2013). Daha sonrasında, dünyadaki gelişmelere paralel olarak 1960’lı yıllarda Milli Eğitim Bakanlığı (MEB) ortaöğretimde fizik öğretimini geliştirmeye yönelik çalışmalara devam etmiştir. 1961'de Ders Araçları Yapım ve Onarım Merkezi'nin kurulması, 1964'te modern fen programlarının (PSSC fiziği gibi) uygulanacağı Ankara Fen Lisesi'nin açılması, 1967'de Fen Öğretimi Geliştirme Bilimsel Komisyonu'nun kurularak 1963'te kurulan Türkiye Bilimsel ve Teknolojik Araştırma Kurumu (TÜBİTAK) ile işbirliği içinde fen programlarının geliştirilmesi çalışmaları bu dönemlere rastlamaktadır. Ülkemizde öğretim programlarındaki gelişmeler dünya ile paralellik gösterse de, fizik eğitimi alanındaki bilimsel araştırmaların geçmişi ancak 1990'lı yıllara dayanmaktadır (Sözbilir \& Canpolat, 2006). Bu yılların öncesinde çok az sayıda bilimsel araştırmaya rastlanır. 1997 yllında eğitim fakültelerinin yeniden yapılanmasıyla birlikte ise Türkiye'de fizik eğitimi araştırmaları büyük bir ivme kazanmıştır.

Fizik eğitimi öncelikle öğrencilerin fizikle ilgili problemlerini tespit etmeyi ve pedagojik araçlar ve yöntemler geliştirerek ilköğretimden üniversiteye her seviyede öğrencilerin fiziği anlamasına yardım etmeyi amaçlar (Didiş, 2012). Birçok öğrenci fizikle ilgili sorun yaşamakta, fiziği olguların ve formüllerin toplamı olarak görmekte, fiziği günlük hayatla ilişkilendirememekte ve fizik problemlerini çözememektedir (Hammer \& Elby, 2003). Birçoğu sınavlarda iyi notlar alsalar da, öğrencilerde kavram yanılgıları, problem çözme becerilerinde zayıflık ve fizik yasalarını yorumlamada güçlükler görülmektedir (Reif, 1995). Bu sebeplerle, kavram bilgisi, matematiksel beceriler ve mantıksal akıl yürütme arasındaki ilişkilerin anlaşılması, öğrencilerin daha iyi problem çözücüler olmasına yardım edilmesini kolaylaştıracaktır (Heron \& Meltzer, 2005). Öğrencilerin fizik bilgileri gibi, fizikle ilgili sahip oldukları olumsuz deneyimler, fikirler, inanışlar ve beklentiler birçok farklı kaynak sebebiyle olabilir. Fakat biz fizik eğitimcileri olarak bu olumsuz durumları olumluya çevirmeye fizik öğretimini revize ederek başlayabiliriz. Örneğin, Redish ve Steinberg (1999) öğrencilerin fizikte zorluk çekmelerinin sebebini fiziğe giriş derslerinin yapısı olduğunu açıklamıştır. Bu derslerin yaklaşımı, ileri düzeyde çalışmalara temel sağlamak için matematiksel işlemler ve yapıları vurgulamak olduğu gibi bir sonraki konuya bağlam hazırlamak için birçok fizik konusunun yüzeysel geçilmesidir. McDermott $(1991,1993,1997)$ öğretmenlerin ne anlattığı ile öğrencilerin ne anladığı arasında bir uyumsuzluk olduğunu vurgulamıştır. Birçok öğretmen geleneksel öğretimde öğrencileri kendilerinin genç versiyonları olarak görmekte ve öğrencilerin algılarının ve hazır bulunuşluklarının fizik öğrenmede nasıl kaygı yarattığından haberdar değildirler. 
Yapılandırmacı öğretim kuramına göre öğrenciler yaşadıkları çevre ve çevredeki diğer bireylerle olan etkileşimleri neticesinde yeni bilgilerini oluştururlar (Vygotsky, 1978). Bunu gerçekleştirirken eski bilgilerini ve var olan mevcut bilgi ve deneyimlerini tekrar gözden geçirme yoluna giderler. Bu sebeple öğrencilerin sinıfa ne getirdikleri konusunda haberdar olmak çok önemlidir çünkü bu bilgiler sınıfta yeni sunulan bilgiler ile etkileşime girmektedir. Halloun ve Hestenes (1985a, 1985b) ile Hestenes, Wells ve Swackhamer (1992) birçok öğrencinin fizik öğrenmesinde önemli rolü olan iyi kurulmuş sezgisel inanışlar sisteminden bahsetmişlerdir. Bunun sonucunda araştırmacılar öğretimde ön kavramların dikkate alınmasını ve etkili fizik öğretiminde kavramsal anlamanın teşvik edilmesi gerektiğini önermişlerdir (Dykstra, Boyle, \& Monarch, 1992). Lillian McDermott başta olmak üzere diğer araştırmacılar ve araştırma grupları fizikte çeşitli konularda öğrencilerin sahip oldukları kavram yanılgılarının tespiti üzerine çeşitli araştırmalar gerçekleştirmiş ve bu tespitler çerçevesinde kavramsal öğrenmeyi sağlamayı amaçlayan araştırma-temelli öğretim materyalleri geliştirilmiştir. Kavram yanılgılarının tespit edilmesi amaciyla Kuvvet Kavram Testi (FCI) (Hestenes, Wells, \& Swackhamer, 1992), Mekanik Testi (MBT) (Hestenes \& Wells, 1992), Kuvvet ve Hareket Kavram Testi (FMCE) (Thornton \& Sokoloff, 1998), Kinematik Grafik Anlama Testi (TUG-K) (Beichner, 1994), Elektrik ve Manyetizma Ölçme Aracı (BEMA) (Ding, Chabay, Sherwood, \& Beichner, 2006), Direnç Devrelerinin Yorumlanması ve Tespiti Testi (DIRECT) (Engelhardt \& Beichner, 2004), Işık ve Spektroskopi Kavram Testi (LSCI) (Bardar, Prather, Brecher, \& Slater, 2007), Dört Aşamalı Geometrik Optik Testi (FTGOT) (Kaltakci Gurel, Eryilmaz, \& McDermott, 2017), Mekanik Dalgalar Kavram Testi (Tongchai, Sharma, Johnston, Arayathanitkul \& Soankwan, 2009), Üç Aşamalı Isı ve Sicaklık Testi (Eryılmaz, 2010), Basit Elektrik Devreleri Tanı Testi (SECDT) (Peşman \& Eryılmaz, 2010), Elektrik Kavram Testi (Aykutlu \& Şen, 2012) gibi başlıca kavramsal testler geliştirilip yaygın olarak kullanılmıştır. Kaltakci Gurel, Eryilmaz ve McDermott (2015) fizik eğitimi alanında kullanılan kavramsal ve çok aşamalı diğer kavram yanılgısı testlerini listelemişlerdir. Kavram yanılgılarının belirlenmesine ek olarak, kavramsal öğrenmeyi sağlamak amacıyla geliştirilen araştırma-temelli öğretim materyallerinden bazıları ise şu şekilde sıralanabilir (Beichner, 2009; McDermott, 2012; Rebello \& Zollman, 2005):

- Sorgulama Yoluyla Fizik (Physics by Inquiry) (McDermott, 1996) ${ }^{3}$ : Washington Üniversitesi tarafindan geliştirilip uygulanan basit araçlarla yaparak öğrenme (hands-on) etkinlikleriyle fen ve fizik öğretmen adayları ile fen ve fizik ögretmenlerine hitap eden sorgulamaya dayalı öğrenme temelli bir öğretim materyalidir.

- Çalıştay Fiziği (Workshop Physics) (Laws, 1991): Bu öğretim materyali dört aşamalı bir öğrenme serisini içermektedir. Öğrencilerden ilk olarak bir olay hakkında tahmin yapmaları istenmektedir. Sonra olayı gözlemleyip, bu gözlemleri hakkında yorum yapmaları istenmektedir. Eğer tahminleri ile gözlemleri arasında bir farklılık mevcut ise bunu açıklamaları istenmektedir. İkinci aşamada, öğrencilerden tahmin ve gözlemlerine dayanarak teorik olarak tanım ve denklemlerini geliştirmeleri istenmektedir. Üçüncü aşamada, deneyler yaparak teoriye bağlı olarak geliştirdikleri tahminlerini doğrulamaya çalışırlar. Son olarak ise, öğrencilerden öğrendiklerini problem çözümlerine uygulamaları istenmektedir.

- Stüdyo Fiziği (Studio Physics) (Wilson, 1994): Öğrencilerin klasik sınıflar yerine birbirleriyle etkileşim halinde olabilecekleri masaların etrafinda oturduğu stüdyo tarzı dersliklerde gerçekleştirilen ve her masada bulunan bilgisayarlarla teknoloji temelli derslerin gerçekleştirildiği araştırma temelli bir öğretim programıdır. Kuzey Carolina Eyalet Üniversitesi'nde Robert J. Beichner ve grubu tarafindan uygulanan "Scale-Up" Projesi de stüdyo fiziğinin bir uygulamasıdır.

- Sokratik Diyalog Laboratuvarlarl (Socratic Dialog Laboratories) (Hake, 1992): Indiana Üniversitesi'nde geliştirilen ve üniversite mekanik giriş derslerinde öğrencileri hem zihinsel ve hem de fiziksel olarak aktif kılan etkileşimli laboratuvar uygulamalarıdır.

- Etkileşimli Ders Gösterileri (Interactive Lecture Demonstrations) (Sokoloff \& Thornton, 1997): Öğrencilerin çeşitli etkinliklerle fizikte belli kavramlara dair önbilgilerini ortaya çıkarıp onlarla yüzleşmelerini sağlamak amaçlanmaktadır. Bu etkinlikler bazen bir deney, bazen bir soru, bazen bir simülasyon olabilmektedir.

- Fizikte Modelleme (Modeling Physics) (Wells, Hestenes, \& Swackhamer, 1995): Arizona Üniversitesi’nce hem lise hem de üniversite fizik derslerinin geliştirilmesi amacıyla geliştirilen, sorgulama temelli olarak temel becerileri, matematiksel modellemeyi, orantısal muhakemeyi ve teknoloji yardımıyla veri toplama ve analizini sağlayan bir öğretim programıdır. 
- Akran Öğretimi (Peer Instruction) (Mazur, 1997): Kalabalık sunıflarda öğrencilerin zihinsel olarak öğretime katılmalarını amaçlayan bir yöntemdir. Bu yöntemde öğretmen dersi kısa kısa bölümlere (15'er dakikalık) ayırarak teorik anlatımların yanı sıra nitel sorular yöneltip özellikle kavram yanılgılarını ortaya çıkarmaya çalışmaktadır. Bu yaklaşımda öğrencilerin akranları ile etkileşimleriyle kavramsal anlamaya sahip olmaları amaçlanır.

- Fizikte Ögreticiler (Tutorials in Physics) (McDermott \& Shaffer, 1998): Washington Üniversitesi tarafindan fen bilimleri ve mühendislik alanları için düzenlenmiş üniversite seviyesindeki fizik giriş derslerinde (mekanik; elektrik ve manyetizma; optik ve dalgalar) kullanılan araştırmaya dayalı ögretim materyalleridir. Özellikle öğrencilerde yaygın olarak mevcut olan kavram yanılgılarının tespiti ve giderilmesine dönük hazırlanan bu materyaller, standart düz anlatıma sahip fizik derslerine ve bu derslerin laboratuvar uygulamalarına destek sağlamayı amaçlamaktadır.

- Gerçek Zaman Fiziği ve Mikrobilgisayar Temelli Laboratuvarlar (RealTime Physics and Microcomputer Based Laboratories-MBL) (Sokoloff, Thornton, \& Laws, 1999): Bu materyaller, öğrencilerin çeşitli sensörlere sahip mikrobilgisayarlar yardımıyla kendi hareketlerinin anında grafiğini çizmelerini sağlamakta ve aynı zamanda anlık geri dönütlerle hareketleriyle bu harekete ait grafiği eşleştirmelerine olanak sağlamayı amaçlamaktadır.

Fizik öğretiminde bir diğer önemli konu ise bilgilerin organize edilmesidir. Öğrenciler zihinlerinde her zaman tutarlı yapılara sahip olmamakta, bu sahip oldukları parçalı (fragmented) yapıları (phenomenological primitives: p-prims) kullanarak fiziksel olguları açıklamaya çalışmaktadır (diSessa, 1983). Reif (1995, 1997) fiziğin öğrenilmesinde bilgi organizasyonun önemine işaret etmiş ve hiyerarşik bilgi organizasyonunun gerekli olduğunu, çünkü tutarsız ve ayrık bilgilerin fizikte problem çözümüne iyi bir temel sağlamadığına dikkat çekmiştir. Öğrencilerin fiziğin birçok formül ve yasaların ezberlenmesini gerektirdiğini düşünmesine rağmen iyi bir fizikçi olmak, detayları hatırlamaya ve çıkarım yapmaya imkân verecek organize edilmiş bilgiye sahip olmayı gerektirir (Reif, 1995). Öğrencilerin bilgilerinin karmaşık yapısına rağmen araştırmalar bilginin nasıl organize edildiği ile ilgilenmişlerdir. İncelenen bilgi yapıları nitel ve nicel olarak araştırılarak öğrencilerin düşünmelerindeki dinamik yapı modellenmeye çalışılmıştır (Bao \& Redish, 2006; Borges \& Gilbert, 1999; Chiou \& Anderson, 2010; Corpuz \& Rebello, 2011; Didiş, Eryılmaz, \& Erkoç, 2014; Hrepic, Zollman, \& Rebello, 2010; Hubber, 2006; Itza-Ortiz, Rebello, \& Zollman, 2004; Özcan, 2015; Wittmann, Steinberg, \& Redish, 1999).

Fizik eğitiminde, öğrencilerin öğrenmelerine ilişsin bilişsel alana ek olarak, duyuşsal alanda araştırmaların da yapılması son derece önemlidir. Fizik öğreticilerinin göz önünde bulundurması gereken diğer bir durum ise öğrencilerin fizikle ilgili geçmiş durumlarından haberdar olmaları ve öğrencilerin gelecekte fizikten ne beklediklerini bilmeleri gerektiğidir. Öğrencilerin beklentileri hakkında fikir sahibi olunduğunda bu beklentiler dikkate alınmalıdır. Çünkü bu beklentiler öğrencilerin kendi bilgilerini kurarken seçecekleri aktiviteleri etkileyecektir (Redish, Saul, \& Steinberg, 1998). Öğrencilerin fizikten beklentilerine ek olarak, fizik öğrenme ile ilgili motivasyonları, tutumları ve inanışları gibi diğer muhtemel duyuşsal değişkenler de fizik eğitimcileri tarafindan incelenmiş ve uluslararası uygulanabilen anketler geliştirmiş̧lerdir. Bu anketlerden bazıları şunlardır: EBAPS-Fiziksel Bilimler için Epistemolojik İnanışların Ölçümü (White, Elby, Frederiksen, \& Schwarz, 1999), MPEX-Maryland Fizik Beklentileri Anketi (Redish, Saul, \& Steinberg, 1998), CLASS- Colorado Bilimle Alakalı Öğrenme Tutumları Anketi) (Colorado Physics Education Research Group, 2004), VASS-Bilimle Alakalı Görüssler Anketi (Halloun \& Hestenes, 1998). Ülkemizde de fizik eğitiminde bu duyuşsal özellikleri ölçücü anketlerin birçoğu bu uluslararası anketlerden doğrudan dilimize uyarlanmıştır (Aslan \& Taşar, 2013; YerdelenDamar, Elby, \& Eryılmaz, 2012). Ülkemizde revize edilerek uyarlanan bu anketlerin (Azar, Şenler, \& Taşkın, 2006; Taşlıdere \& Eryılmaz, 2012) orijinallerinden farkı fiziğin alt alanına özgü (mesela elektrik, optik, mekanik vs.) olmasidir.

Bilgisayar temelli teknolojideki gelişme fizik eğitimine de yansımıştır. Stern Gerlach Deneyi gibi teknik olarak karmaşık ve pahalı deney düzenekleri fizik öğretici ve program geliştiricilerin birçok fizik kavramını simülasyon, animasyon ve çoklu ortam (multimedia) sunum olarak geliştirmesine ve öğretimlerinde kullanmalarına imkân vermiştir. Bu teknolojinin öğrencilerin soyut kavramları, bilimsel modellerin doğası ve gerçek dünya ile ilişkisini anlamasına etkisinin ölçülmesi zorlu bir iştir. Bu sebeple bilgisayar temelli öğretim araçlarının geliştirilmesinde bu araştırmalar önemli role sahiptir (Heron \& Meltzer, 2005). 
Fizik eğitimi araştırma alanı olarak birçok farklı disiplinle etkileşimde olduğu için disiplinler arası bir yapıdadır (Duit, Niedderer, \& Schecker, 2007). Şekil 1'de fizik eğitiminin doğrudan etkileşimde olduğu temel disiplinler şematize edilmiştir.

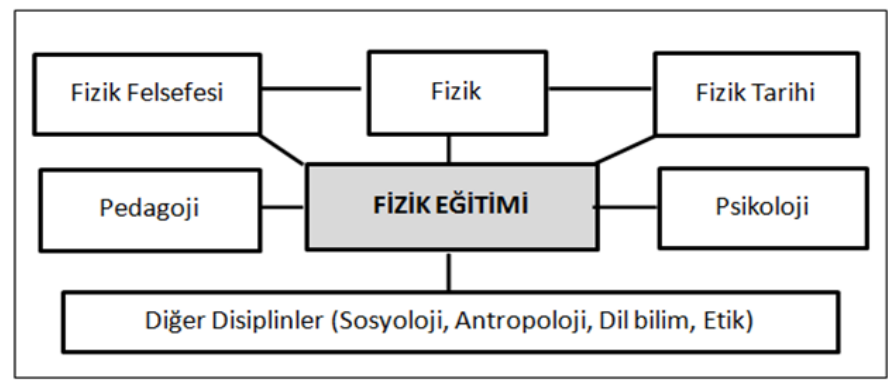

Şekil 1. Fizik Eğitiminin Doğrudan Etkileşimde Olduğu Disiplinler (Duit vd., 2007)

Şekil 1'de görüldüğü gibi fizik eğitimi, fizik, psikoloji, pedagoji vb. gibi birçok disiplin ile ilişkili ve etkileşim halindedir. Fiziğin doğasını oluşturan fizik tarihi ve fizik felsefesi gibi alanlar fiziğin kendini etkilediği gibi fiziğin nasıl öğretilip nasıl öğrenileceğini de etkilemektedir. Sosyal bilimlerin alt disiplinleri olan pedagoji ve psikoloji de fizik eğitimini doğrudan etkileyen temel disiplinler arasındadır. Bu disiplinler matematik, bilişsel bilimler ve eğitim bilimleri gibi başka disiplinler ile daha da genişletilebilir. Fizik eğitiminin bu disiplinler arası yapısı, fizik eğitimi araştırmalarına zenginlik kattığı gibi, çalışma bulgularının farklı disiplinlerce yorumlanması bu alanlar arasında etkileşimli bir ilişkiye imkân vermiştir. Disiplinler arası yapının diğer bir faydası da bulguların geniş kitlelere yayılmasında rolü olmasıdır. Bu sebeple, fizik eğitimi ve ögretimi ile ilgili birçok akademik çalışmanın bulguları çeşitli disiplinlere ait dergilerde yer aldığı gibi çoğunlukla fizik, fizik eğitimi ve fen eğitimi dergilerinde yayınlanarak bu alanda çalışan araştırmacılar ve öğretmenlerle paylaşılmaktadır. Fizik eğitimi ile ilgili çalışmaları bulabileceğimiz indekslerce taranan birçok dergi tüm dünyada olduğu gibi ülkemizde de faaliyet göstermekte ve bu sayı her geçen gün hızla artmaktadır. Fizik eğitiminin disiplinler arası yapısı sebebiyle bu dergiler doğa bilimlerine ait makalelerin yayınlandığı fizik dergileri olabildiği gibi, eğitim bilimlerine ait dergiler de olabilmektedir. Bu dergilerden bazıları ise bu disiplinler arası yapıyı genel olarak yansıtan fen eğitimi dergileri ile daha spesifik olarak yansıtan fizik eğitimi dergileridir. Tablo 1'de bu alanda yayın yapan başlıca dergiler - fizik ve fizik eğitimi dergilerinin tamamı ile fen eğitimi ve eğitim bilimleri dergilerinin ulusal ve uluslararası literatürde tanınırlığı dikkate alınarak- listelenmiş ve bu dergilerin yayın sıklıklarının neler olduğu sunulmuştur.

Tablo 1. Fizik Eğitimi Alanında Yayın Yapan Başlıca Dergiler

\begin{tabular}{|c|c|c|c|}
\hline Dergi Adı & $\begin{array}{l}\text { Yayın Sıklı̆̆ı } \\
\quad \text { (Yılda) }\end{array}$ & $\begin{array}{l}\text { Ulusal/ } \\
\text { Uluslararası }\end{array}$ & İlgili Temel Alan \\
\hline $\begin{array}{l}\text { Physical Review Special Topics-Physics Education } \\
\text { Research (PRST-PER) }\end{array}$ & 2 say1 & Uluslararası & Fizik Eğitimi \\
\hline The Physics Teacher (TPT) & 9 say1 & Uluslararası & Fizik Eğitimi \\
\hline Physics Education & 6 say1 & Uluslararas1 & Fizik Eğitimi \\
\hline Fizik Eğitimi ve Felsefesi & 2 say1 & Uluslararas1 & Fizik Eğitimi \\
\hline European Journal of Physics (EJP) & 6 say1 & Uluslararası & Fizik \\
\hline American Journal of Physics (AJP) & 12 sayı & Uluslararası & Fizik \\
\hline Journal of Research in Science Teaching (JRST) & 10 sayı & Uluslararas1 & Fen Eğitimi \\
\hline Science Education & 6 say1 & Uluslararası & Fen Eğitimi \\
\hline Science \& Education & 10 say1 & Uluslararas1 & Fen Eğitimi \\
\hline International Journal of Science Education (IJSE) & 18 say1 & Uluslararas1 & Fen Eğitimi \\
\hline Research in Science Education (RISE) & 6 say1 & Uluslararas1 & Fen Eğitimi \\
\hline $\begin{array}{l}\text { International Journal of Science and Mathematics } \\
\text { Education }\end{array}$ & 6 say1 & Uluslararası & $\begin{array}{l}\text { Fen ve Matematik } \\
\text { Eğitimi }\end{array}$ \\
\hline $\begin{array}{l}\text { Eurasia Journal of Mathematics, Science and Technology } \\
\text { Education }\end{array}$ & 6 sayı & Uluslararası & $\begin{array}{c}\text { Fen ve Matematik } \\
\text { Eğitimi }\end{array}$ \\
\hline Türk Fen Eğitimi Dergisi (TÜFED) & 4 say1 & Ulusal & Fen Eğitimi \\
\hline Hacettepe Eğitim Fakültesi Dergisi & 4 sayı & Uluslararas1 & Eğitim Bilimleri \\
\hline Eğitim ve Bilim & 4 say1 & Uluslararas1 & Eğitim Bilimleri \\
\hline
\end{tabular}




\begin{tabular}{llll}
\hline Eğitim Araştırmaları Dergisi (EJER) & 4 sayı & Uluslararası & Eğitim Bilimleri \\
\hline Kuram ve Uygulamada Eğitim Bilimleri (KUYEB) & 6 sayı & Uluslararası & Eğitim Bilimleri \\
\hline
\end{tabular}

Araştırma temelli öğretim yöntemlerinin uygulanması neticesinde elde edilen akademik ve duyuşsal başarılar, bu alanda doktora yapmayı teşvik etmeye ve devlet bütçesinden bu alanda yapılan araştırmalara daha fazla destek verilmesine neden olmuş, böylece ABD'de ileri gelen üniversitelerde fizik bölümleri altında açılan fizik eğitimi anabilim dallarının sayısı artmıştır (Heron \& Meltzer, 2005; McDermott, 2012). Ülkemizde ise fizik eğitimi üniversitelerde yerel ve birbirinden bağımsız olarak çalışılmakta olup bu alanlara devlet bütçesinden teşvikler ile fizik eğitimi alanında doktora yapan araştırmacılardaki artış ABD ile paralellik göstermektedir. Ülkemizde yapılan fizik eğitimine yönelik lisansüstü tezlerin (Kaltakçı-Gürel vd., 2017a), hakemli dergilerde yayınlanan makalelerin (Kaltakçı-Gürel vd., 2017b; Önder vd., 2014) ve ulusal kongrelerde sunulan bildirilerin (Kanlı vd., 2014) yıllara, araştırma alanlarına, kullanılan yöntem ve analizlere göre incelendiği içerik analizi çalışmaları bu durumu ortaya koymaktadır. Fakat her ne kadar devlet desteği ve araştırmacı sayılarındaki artış benzer olsa da dünyada fizik eğitimi belli araştırma gruplarına odaklanan, farklı disiplinlerden araştırmacıları içeren merkezi araştırma gruplarında çalışılmakta, ülkemizde ise bu durum eğitim fakültesinde ilgili bölümlerdeki öğretim elemanlarının işbirlikleri ile etkileşimli olarak yürütülmektedir. Tablo 2, dünya çapında fizik eğitimi alanında öncü başlıca fizik eğitimi araştırma gruplarını sunmaktadır.

Tablo 2. Başlıca Fizik Eğitimi Araştırma Grupları

\begin{tabular}{|c|c|c|c|}
\hline Grup Adı & Üniversitesi & Çalıştıkları Temel Konular & $\begin{array}{l}\text { Başlıca } \\
\text { Araştırmacılar }\end{array}$ \\
\hline PEG & $\begin{array}{l}\text { Washington Üniversitesi, } \\
\text { ABD }\end{array}$ & Sorgulama yoluyla fizik & $\begin{array}{l}\text { Lillian C. McDermott } \\
\text { Paula Heron }\end{array}$ \\
\hline UMDPERG & $\begin{array}{l}\text { Maryland Üniversitesi, } \\
\text { ABD }\end{array}$ & $\begin{array}{l}\text { Zihinsel modeller, } \\
\text { Epistemoloji, } \\
\text { MPEX }\end{array}$ & $\begin{array}{l}\text { Edward F. (Joe) } \\
\text { Redish }\end{array}$ \\
\hline K-SUPER & $\begin{array}{l}\text { Kansas Eyalet Üniversitesi, } \\
\text { ABD }\end{array}$ & Zihinsel modeller & Dean Zollman \\
\hline PER@C & $\begin{array}{l}\text { Colorado Üniversitesi, } \\
\text { ABD }\end{array}$ & $\begin{array}{l}\text { İnteraktif Fizik } \\
\text { Simülasyonları, } \\
\text { İleri fizik derslerinin geliştirilmesi, } \\
\text { CLASS }\end{array}$ & $\begin{array}{l}\text { Steven Pollock } \\
\text { Noah Finkelstein } \\
\text { Valerie Otero }\end{array}$ \\
\hline Mazur Grubu & Harvard Üniversitesi, ABD & Akran Öğretimi & Eric Mazur \\
\hline ASU-PER & $\begin{array}{l}\text { Arizona Eyalet Üniversitesi, } \\
\text { ABD }\end{array}$ & $\begin{array}{l}\text { Modelleme, } \\
\text { Fizik öğretmen eğitimi }\end{array}$ & $\begin{array}{l}\text { David Hestenes } \\
\text { David Meltzer }\end{array}$ \\
\hline PERL & Maine Üniversitesi, ABD & Aktivite temelli fizik & $\begin{array}{l}\text { Michael C. Wittman } \\
\text { MacKenzie R. Stetzer }\end{array}$ \\
\hline SESAME & $\begin{array}{l}\text { Kaliforniya Üniversitesi } \\
\text { Berkeley, ABD }\end{array}$ & Epistemoloji & Andrea diSessa \\
\hline PER & $\begin{array}{l}\text { Dickinson Üniversitesi, } \\
\text { ABD }\end{array}$ & Çalıştay Fiziği & Priscilla Laws \\
\hline PER & $\begin{array}{l}\text { Minnesota Üniversitesi, } \\
\text { ABD }\end{array}$ & Bağlamsal problemler & $\begin{array}{l}\text { Patricia Heller } \\
\text { Kenneth Heller } \\
\text { (emekli) }\end{array}$ \\
\hline CRMSE & $\begin{array}{l}\text { San Diego Eyalet } \\
\text { Üniversitesi, ABD }\end{array}$ & $\begin{array}{l}\text { Fizik ve Gündelik } \\
\text { Düşünce }\end{array}$ & Fred Goldberg \\
\hline SUPER & $\begin{array}{l}\text { Sydney Üniversitesi, } \\
\text { Avustralya }\end{array}$ & $\begin{array}{l}\text { Kavramsal fizik ögretimi ve } \\
\text { kavramsal testler, } \\
\text { Multimedya }\end{array}$ & Manjula Sharma \\
\hline $\begin{array}{l}\text { Fen Eğitimi Araştırma } \\
\text { Birimi }\end{array}$ & $\begin{array}{l}\text { Wiezman Fen Enstitüsü, } \\
\text { İsrail }\end{array}$ & $\begin{array}{l}\text { Kavramsal fizik öğretimi, } \\
\text { Öğretmen eğitimi }\end{array}$ & Bet-Sheva Eylon \\
\hline $\begin{array}{l}\text { URDF (Fizik Eğitimi } \\
\text { Araştırma Birimi) } \\
\text { CLDF (Fizik Eğitimi } \\
\text { Araştırma Laboratuvarı) }\end{array}$ & Udine Üniversitesi, İtalya & $\begin{array}{l}\text { Fizik öğretmen eğitimi, } \\
\text { Zihinsel modeller }\end{array}$ & Marisa Michelini \\
\hline
\end{tabular}




\begin{tabular}{llll}
\hline $\begin{array}{l}\text { The Division of Physics } \\
\text { Education }\end{array}$ & Uppsala Üniversitesi, İsveç & $\begin{array}{l}\text { Yükseköğretim, } \\
\text { Bilimsel okuryazarlık }\end{array}$ & Cedric Linder \\
\hline $\begin{array}{l}\text { Physics Teacher } \\
\text { Education }\end{array}$ & $\begin{array}{l}\text { Helsinki Üniversitesi, } \\
\text { Finlandiya }\end{array}$ & Fizik öğretmeni eğitimi & Ismo Koponen \\
\hline
\end{tabular}

Tablo 2'de fizik eğitimi alanına yön verici bazı fizik eğitimi araştırma grupları özetlenmiştir. Bu araştırma grupları çoğunlukla ABD merkezli olsa da ABD dışında da bu grupların yakın zamanda artacağı öngörülmektedir. Bu artışta şüphesiz ki bu araştırma grupları ile uluslararası ortaklıkların etkin yeri olacaktır. Ülkemiz için ele alacak olursak, fizik eğitimi alanında yurt dışında doktora yapan araştırmacılar ülkemize geri dönmekte ve üniversitelerde akademik pozisyon sahibi olmaktadır. Ayrıca, doktora süresince devlet desteği ile yurt dışında bu araştırma gruplarında araştırma yapma, sosyal ve akademik deneyim edinmiş araştırmacılar da fizik eğitimi araştırmalarının artmasını ve uluslararası araştırma grupları ile daha kapsamlı ve karşılaştırmalı araştırmalar yapılmasını sağlayacaktır. Ulusal ve uluslararası işbirliğinde diğer bir önemli nokta da alana özgü araştırmaların sunulması ile bir birçok araştırmacıyı bir araya getiren konferanslardır. Fizik eğitimi alanında günümüzde birçok ulusal ve uluslararası kongre ve konferans düzenlenerek, bu alanda çalışan araştırmacıların bilgi alışverişinde bulunmaları sağlanmaktadır. Bu alandaki düzenlenen etkinlikler de tıpkı fizik eğitimi araştırmaları gibi doğrudan fizik ve fizik eğitimi etkinlikleri veya fen alanının bir alt disiplini olarak fizik eğitimi etkinlikleri olmak üzere iki grupta toplanabilmektedir. Tablo 3'te bu alanda yapılan başlıca kongre ve konferanslar düzenlenme sıklıkları ile birlikte listelenmiştir.

Tablo 3. Fizik Eğitimi Alanında Yapılan Başlıca Ulusal ve Uluslararası Etkinlikler

\begin{tabular}{|c|c|c|c|}
\hline Etkinliğin Adı & Düzenlenme Sıklığı & Ulusal/Uluslararası & İlgili Temel Alan \\
\hline Physics Education Research Conference (PERC) & Y1lda bir & Uluslararas1 & Fizik Eğitimi \\
\hline $\begin{array}{l}\text { American Association of Physics Teachers } \\
\text { (AAPT) }\end{array}$ & Y1lda iki & Uluslararas1 & Fizik Eğitimi \\
\hline $\begin{array}{l}\text { International Conference on Physics Education } \\
\text { (ICPE) }\end{array}$ & $\begin{array}{c}\text { Y1lda bir ya da iki } \\
\text { yılda bir }\end{array}$ & Uluslararası & Fizik Eğitimi \\
\hline $\begin{array}{l}\text { The International Research Group on Physics } \\
\text { Teaching (GIREP) }\end{array}$ & Yilda bir & Uluslararas1 & Fizik Eğitimi \\
\hline $\begin{array}{l}\text { Multimedia in Physics Teaching and Learning } \\
\text { (MPTL) }\end{array}$ & Y1lda bir & Uluslararası & Fizik Eğitimi \\
\hline $\begin{array}{l}\text { Physics Teacher Education Coalition Conference } \\
\text { (PTEC) }\end{array}$ & Y1lda bir & Uluslararas1 & Fizik Eğitimi \\
\hline $\begin{array}{l}\text { Physics Teaching in Engineering Education } \\
\text { Conference (PTEE) }\end{array}$ & İki ya da üç yılda bir & Uluslararası & Fizik Eğitimi \\
\hline Gordon Research Conferences (GRC) & Y1lda bir & Uluslararas1 & Fizik Eğitimi \\
\hline Ulusal Fizik Eğitimi Kongresi (UFEK) & İki yllda bir & Ulusal & Fizik Eğitimi \\
\hline $\begin{array}{l}\text { Türk Fizik Derneği Uluslararası Fizik Kongresi } \\
\text { (TFD) }\end{array}$ & Y1lda bir & Uluslararas1 & Fizik \\
\hline American Physical Society Meeting (APS) & Y1lda birden fazla & Uluslararas1 & Fizik \\
\hline $\begin{array}{l}\text { International Physics Conference of the Balkan } \\
\text { Physical Union (BPU) }\end{array}$ & Üç y1lda bir & Uluslararas1 & Fizik \\
\hline $\begin{array}{l}\text { National Association for Research in Science } \\
\text { Teaching (NARST) }\end{array}$ & Y1lda bir & Uluslararas1 & Fen Eğitimi \\
\hline $\begin{array}{l}\text { European Science Education Research } \\
\text { Association (ESERA) }\end{array}$ & İki yılda bir & Uluslararas1 & Fen Eğitimi \\
\hline $\begin{array}{l}\text { The International Organization for Science and } \\
\text { Technology Education Symposium (IOSTE) }\end{array}$ & Y1lda bir & Uluslararas1 & Fen Eğitimi \\
\hline $\begin{array}{l}\text { International Society of Educational Research } \\
\text { (ISER) }\end{array}$ & Y1lda bir & Uluslararas1 & $\begin{array}{c}\text { Fen ve Matematik } \\
\text { Eğitimi }\end{array}$ \\
\hline $\begin{array}{l}\text { Frontiers in Mathematics and Science Education } \\
\text { Research Conference (FISER) }\end{array}$ & Beş yılda bir & Uluslararas1 & $\begin{array}{c}\text { Fen ve Matematik } \\
\text { Eğitimi }\end{array}$ \\
\hline $\begin{array}{l}\text { Ulusal Fen Bilimleri ve Matematik Eğitimi } \\
\text { Kongresi (UFBMEK) }\end{array}$ & İki yılda bir & Ulusal & $\begin{array}{c}\text { Fen ve Matematik } \\
\text { Eğitimi }\end{array}$ \\
\hline
\end{tabular}


Bu başlıca kongre ve konferanslar dışında hem ulusal hem de uluslararası birçok eğitim bilimleri kongre ve konferansında da fizik eğitimine ait çalışmaların tartışıldığı bilinmektedir. Özellikle son yıllarda ülkemizde eğitim alanında geniş kapsamlı gerçekleştirilen ulusal ve uluslararası bilimsel etkinlikler kadar yalnızca fen ve fizik eğitimi odaklı bilimsel etkinliklerin sayısı ve fizik eğitimi alanında çalışan bilim insanlarının bu etkinliklere katılımlarında artış olduğu söylenebilir.

\section{Fizik Eğitimi Araştırmalarına Eleştiriler}

Günümüzde fizik eğitimi araştırmaları, kimya ve biyoloji gibi diğer disiplinlerden farklı olarak hem fizik bölümlerinde hem de eğitim fakültelerinde etkin olarak çalışılmaktadır. Özellikle ABD'de uzun süren çabaların neticesinde resmi olarak fizik bölümlerinde bir alt çalışma alanı olarak kabul görmüştür. Bu sebeple, fizik öğrenme ve öğretme araştırmalarında fizik bölümlerinin önemi büyüktür (Heron \& Meltzer, 2005). Her ne kadar Lillian McDermott gibi alanın bazı önde gelen isimleri aynı fikirde olmasa da, Joe Redish ve Fred Reif gibi isimlerce günümüzde özellikle ABD’de fizik bölümlerince fizik eğitimi alanında yapılan çalışmaların en büyük eksikliğinin teorik altyapılarının yeterince tartışılmıyor olması olarak görülmektedir (Cummings, 2011; Redish, 1994). Özellikle 1970’lerden günümüze kadar süregelen önbilgi ve kavram yanılgıları ile ilgili çeşitli fizik konularında yapılan çalışmalar bir tarafa bırakılacak olunursa, fizik bölümlerinde fizik eğitimi ile ilgilenen gruplarca uzun yıllar yapılan çalışmaların teorik çerçeveleri sınırlı (Redish, 1994), buna rağmen fen eğitimi altında yapılan fizik eğitimi araştırmaları derin ve köklü teorik çerçevelere dayandırılmaktadır. Özellikle araştırmaların sonuçlarının sunumunda ileri istatistik ve araştırma teknikleri uygulanarak, çalışmaların sonuçlarının genellenebilirliği ve tekrarlanabilirliği artırılmıştır. Ancak şu da bir gerçektir ki, içerisinde tartışılan fizik, geliştirilen öğretim yöntemleri ve materyalleri, uygulama alanları bakımından fizik bölümlerince yapılan çalışmalar fen eğitimi alanında çalışan fizik eğitimi araştırmacılarına çok büyük katkılar sağlamış ve sağlamaya devam etmektedir.

Ülkemizde fizik eğitimi çalışmalarının yürütülmesi ABD'de çoğunlukla görülenden farklıdır. Ülkemizde fizik eğitimi, ABD'de kısmen ve Avrupa'da çoğunlukla olduğu gibi eğitim fakültelerinde çalışılmaktadır. Bu durum araştırmalarda ve bunların sonuçlarının hayata geçirilmesinde bir takım farklılıklara sebep olmaktadır. Fizik eğitimi alanındaki çalışmaların bir kısmında fizik bölümleri ile işbirliği yapılmakta ve lisans öğrencilerinin üst düzey fizik konularındaki öğrenmeleri incelenmektedir. Bu durumda bulgular her ne kadar literatüre doğrudan katkı sağlasa da, yeni bilgi ve bulguların pratikte uygulanması sınırlı olabilmektedir. Yani, ABD'deki ve benzeri diğer araştırma gruplarında fizik bölümlerinde yürütülen fizik eğitimi araştırma bulguları hızlıca üniversite fizik öğretimine yansıtılıp dersler iyileştirilirken, ülkemizde bu çok sınırlıdır. Eğitim fakültelerinde yürütülen fizik eğitimi araştırma bulguları daha çok ortaöğretim fizik eğitimi ve fizik öğretmen eğitimi programı ders içeriklerine yansıtılarak pratikte uygulamaya daha yerel anlamda katkı sağlayabilmektedir. Bunlar hem öğretmen adayının alan bilgisi (kavramsal fizik bilgisi) hem de pedagojik alan bilgisinin (bu kavramsal fizik bilgisinin fizik öğretiminde kullanılması) iyileştirilmesi şeklinde olabilmektedir. Fizik eğitimi araştırmalarının öneminin artması ve yaygınlaşmasıyla fizik bölümleri ile eğitim fakültelerinin güçlerini birleştirerek yapacakları ortak çalışmaların artacağı öngörülmektedir. Bunun en güzel örneklerden biri olarak ülkemizde ilköğretim fen bilimleri ile ortaöğretim fizik öğretim programlarının geliştirilmesi sürecinde yapılan akademik paylaşımlar verilebilir. Öğretim programlarının hazırlanması sürecinde diğer uzmanlık alanları (kimya, matematik, psikoloji vb.) yanında hem fizik hem de eğitim fakültesi kökenli araştırmacılar bir araya gelerek teorik altyapısı sağlam olduğu kadar kavramsal açıdan da sıkıntıları en aza indirilmiş bir öğretim programı ortaya çıkarmışlardır.

Bir diğer eleştiri ülkemizde fizik eğitimi araştırma gruplarının fazla yaygın olmayışı ve bu sebeple bu alanda yapılan çalışmaların daha çok bireysel nitelikte oluşudur. Ülkemizde 13 eğitim fakültesi altında ortaöğretim fizik öğretmenliği bölümü bulunmakta ve bu bölümlerde doktora programları yer almaktadır. Ayrıca birçok üniversitede fen eğitimi altında da fizik eğitimi çalışan akademisyenler, yüksek lisans ve doktora öğrencileri bulunmaktadır. Buna karşın, fizik eğitimindeki araştırmaların küçük bütçeli, birbirinden bağımsız ve araştırmacıların bireysel çalışmalarının ürünü olduğu görülmektedir. Yurt içinde ve yurt dışında doktora çalışmalarını tamamlayan fizik eğitimcilerin artması ile ülkemizde de aktif araştırma yapan fizik eğitimi gruplarının oluşması beklenmektedir.

\section{Sonuç: Fizik Eğitimi Araştırmalarında Dönüşüm}

1970’lerde başlayan fizik eğitimi araştırmaları ilk başlarda öğrencilerin temel fizik derslerinde (mekanik ve elektrik gibi) geçen kavramları kullanma becerisine odaklanmış ve bu çalışmalar fizik öğretiminin geliştirilmesinde paha biçilmez rol oynamıştır. Günümüzde ise bu çalışmalar kinematik, temel elektromanyetizma 
ve modern fizik konularının da dahil edilmesiyle genişletilmiştir (Heron \& Meltzer, 2005). Son olarak günümüzde yapılan araştırmalar termodinamik, optik, rölativite, kuantum fiziği gibi üst düzey fizik konularının öğrenciler tarafindan nasıl öğrenildiğine odaklanmaktadır. Ülkemizde ise son 25 yıldır ivmelenen fizik eğitimi araştırmaları fizik bölümleri ve fizik eğitimi bölümlerinin arasındaki iletişim eksikliğinden ötürü büyük oranda temel fizik kavramlarının tartışılması seviyesindedir. Mevcut çalışmalar daha çok ilköğretim, ortaöğretim ve öğretmen eğitimi (aday ve hizmette) seviyelerinde yer almaktadır. Oysaki fizik eğitimi alanındaki çalışmaların kapsamı artırılarak temel eğitimden, üniversiteye (temel bilimler ve mühendislik alanları gibi), hatta yetişkin eğitimine (akademisyenler, veliler gibi) kadar uzandırılmalıdır. Böylelikle fen okur-yazarı bir toplum oluşumu konusunda belirlenen temel hedefler yerine getirilmiş olur.

Ulusal ve uluslararası çapta fizik eğitimi (Kaltakçı-Gürel vd., 2017a; Kaltakçı-Gürel vd., 2017b; Kanlı vd., 2014; Önder vd., 2013) ve fen eğitimi (Chang, Chang, \& Tsang, 2010; Lee, Wu, \& Tsai, 2009; Tsai \& Wen, 2005; Tzu-Chiang vd., 2014) alanlarında yapılan içerik analizi çalışmaları alandaki boşlukları ve eksiklikleri göstererek literatüre önemli katkılar sağlar. Önder ve arkadaşları (2013) yaptıkları içerik analizi çalışmasında 2004 ve 2011 yılları arasında Türk Fen Eğitimi Dergisi’nde (TUSED) yayınlanan 46 fizik eğitimi makalesini inceleyerek 'Öğrenme yaklaşımları' ve 'Kavram yanılgıları/öğrenme zorlukları' en fazla çalışmanın olduğu temalar olduğunu, Kanlı ve arkadaşları (2014) da 1994-2012 yılları arasında Ulusal Fen Bilimleri ve Matematik Eğitimi Kongrelerinde (UFBMEK) sunulup tam metini basılan 282 fizik eğitimi çalışmasını inceleyerek 'Fiziğin doğası', 'Epistemoloji ve Bilimsel okuryazarlık', 'Modelleme' ve 'Özel eğitim' en az çalışılan temalar olarak ifade etmişlerdir. Fen eğitimi alanında yapılan uluslararası içerik analizlerinde (Chang et al., 2010; Lee vd., 2009; TzuChiang vd., 2014) ise öne çıkan temalar 'Kavramsal değişim' ve 'Kavram yanılgıları' olarak bulunurken, en az çalışlan alanlar ise 'İnformal öğrenme' ve 'Eğitim teknolojileri' olarak ifade edilmiştir. Fizik eğitimi alanında başvurulan araştırma yöntem ve stratejileri, öğretim yöntemleri, çeşitli ölçme araçları geliştirme veya uyarlamaya yönelik çalışmaların sayısı ve çeşitliliği her geçen gün artmaktadır. Bu sevindirici bir gelişme olmakla birlikte, fizik eğitimi alanında bugüne kadar çalışılan başlıca fizik konularının yanı sıra halen daha fazla araştırmayı gerektiren alt araştırma konuları şu şekilde özetlenebilir: önbilgilerin ve kavram yanılgılarının tespiti, bilgi organizasyonu ve zihinsel modeller, kavramsal değişim, fizik öğretiminde program geliştirme çalışmaları, fizik öğretmen eğitimi ve fizik öğretmeni yeterlilikleri, fizik tarihi ve doğası, fizik öğretiminde teknolojinin yeri, laboratuvar etkinlikleri ve sorgulamaya dayalı öğrenme, problem çözme ve probleme dayalı öğrenme, bağlam temelli fizik öğretimi, fizik öğrenmeyi etkileyen duyuşsal faktörler (motivasyon, tutum gibi), özel eğitime gereksinim duyan bireyler için fizik eğitimi.

Dünyanın çeşitli üniversite veya merkezlerinde bulunan fizik eğitimi araştırma grupları belirli bir alanda uzmanlaşma ve takım çalışması neticesinde çeşitli başarılara imza atıp büyük çapta ve bütçede projeler gerçekleştirirken, ülkemizde de benzer girişimlerin olması gerektiği düşünülmektedir.

Sonuç olarak, fizik eğitimi araştırmaları ilk ortaya çıkışından günümüze kadar büyük ilerleme göstermiş, kendi başına bir araştırma alanı olarak literatürde yerini almışır. Biz fizik eğitimcileri olarak tüm bu bahsedilenler ışığında alanın gelişmesinde çaba göstermeliyiz. Bu çalışmanın "Fizik eğitimi nedir, ne değildir?" sorularına cevap niteliğinde olmasıyla bu alana yeni giren araştırmacılara ışık tutacağına ve yol göstereceğine inanmaktayız. Dünyada ve ülkemizde fizik eğitimi alanında önemli çalışmaları kritik eden bu çalışma fizik eğitimi alanı araştırmacılarının ve bu alanda çalışmaya yeni başlayan yüksek lisans ve doktora öğrencilerinin başvurabileceği Türkçe kaynak olma özelliğini taşımaktadır.

\section{Teşekkür ve Bilgilendirme}

${ }^{1}$ Birinci yazarın Washington Üniversitesi, Fizik Eğitimi Grubu (PEG), Prof. Dr. Lillian C. McDermott danı̧̧manlığında deneyimi.

${ }^{2}$ İkinci yazarın Maryland Üniversitesi, Fizik Eğitimi Araştırma Grubu (UMDPERG), Prof. Dr. Edward F. (Joe) Redish danı̧̧manlığında ve Harvard Üniversitesi, Fizik/Eğitim Araştırma Grubu (Mazur Grubu), Prof. Dr. Eric Mazur danışmanlığında deneyimi.

${ }^{3}$ İlk olarak 1977 yılında kullanılmaya başlanılmıştır ancak resmi olarak kitap 1996 yılında basılmıştır (McDermott, 2012). 


\section{References}

Alvesson, M. \& Deetz, S. (2000). Doing critical management research. London: Sage Pub.

Aslan, O. \& Taşar, M. F. (2013). Fen öğretmenlerinin bilimin doğası görüşleri ve öğretimleri nasıldır? Bir sınıf içi araştırması [How do science teachers view and teach the nature of science? A Classroom Investigation]. Ĕ̈itim ve Bilim, 38 (167), 65-80.

Aykutlu, I., \& Şen, A. İ. (2012). Üç aşamalı test, kavram haritası ve analoji kullanılarak lise öğrencilerinin elektrik akımı konusundaki kavram yanılgılarının belirlenmesi [Determination of secondary School Students' misconceptions about the electric current using a three tier test, concept maps and analogies]. Eğitim ve Bilim, $37(166), 275-288$.

Azar, A., Şenler, B. \& Taşkın, Ö. (2006). Çoklu zeka kuramına dayalı öğretimin öğrencilerin başarı, tutum, hatırlama ve bilişsel süreç becerilerine etkisi [Effect of Multiple Intelligence Theory based instruction on students' achievement, attitude, retention, and process skills]. Hacettepe Üniversitesi Eğitim Fakültesi Dergisi, $30,45-54$.

Bao, L., \& Redish, E. F. (2006). Model analysis: Assessing the dynamics of student learning. Physical Review Special Topics: Physics Education Research, 2(1), 010103 (1-16).

Bardar, E. M., Prather, E. E., Slater, T. F., \& Brecher, K. (2007). Development and validation of the light and spectroscopy concept inventory. Astronomy Education Review, 5(2), 103-113.

Beichner, R. J. (1994). Testing student interpretation of kinematics graphs. American Journal of Physics, 62(8), 750-762.

Beichner, R. (2009). An Introduction to Physics Education Research. In C. Henderson, \& K. A. Harper (Eds.), Getting Started in PER-Reviews in PER, vol 2. http://www.per-central.org/items/detail.cfm?ID=8806 adresinden alınmıştır.

Borges, A., \& Gilbert J. K. (1999). Mental models of electricity. International Journal of Science Education, 21(1), 95-117.

Chang, Y., Chang, C., \& Tsang, Y. (2010). Trends of science education research: An automatic content analysis. Journal of Science and Educational Technology, 19(4), 315-331.

Chiou, G., \& Anderson, O. R. (2010). A study of undergraduate physics students' understanding of heat conduction based on mental model theory and an ontology-process analysis. Science Education, 94, 825- 854.

Colorado Physics Education Research Group (2004). CLASS: Colorado Learning Attitudes about Science Survey. http://www.colorado.edu/sei/class/ adresinden alınmıştır.

Comstock, D. E. (1982). A method for critical research. In E. Bredo \& W. Feinberg (Eds.) Knowledge and values in social and educational research (pp. 370-390), Philadelphia: Temple University Press.

Corpuz, E. D., \& Rebello, N. S. (2011a). Investigating students' mental models and knowledge construction of microscopic friction: Implications for curriculum design and development - Part I. Physical Review Special Topics: Physics Education Research, 7(2), 020102 (1-9).

Cummings, K. (2011). A developmental history of physics education research. A Commisioned Paper Written at the Request of the National Academies' Board on Science Education. http://sites.nationalacademies.org/dbasse/bose/dbasse_080124 adresinden alınmıştır.

Didiş, N. (2012). Investigation of Undergraduate Students' Mental Models About the Quantization of Physical Observables. Unpublished PhD thesis, Middle East Technical University: Ankara.

Didiş, N., Eryılmaz, A., \& Erkoç, Ş. (2014). Investigating students' mental models about the quantization of light, energy and angular momentum. Physical Review Special Topics: Physics Education Research, 10(2), 020127.

Ding, L., Chabay, R., Sherwood, B., \& Beichner, R. (2006). Evaluating an assessment tool: brief electricity and magnetism assessment. Physical Review Special Topics-Physics Education Research, 2(1), 10105-1-10105-7. 
diSessa, A. A. (1983). Phenomenology and the evolution of intuition. In D. Gentner \& A. Stevens (Eds.), Mental models (pp.15-33). Hillsdale, NJ: Lawrence Erlbaum Associates.

Duit, R., Niedderer, H., \& Schecker, H. (2007). Teaching Physics. In S. K. Abell, \& N. G. Lederman (Eds.), Handbook of research on science education (pp.599-629). New Jersey: Lawrence Erlbaum Associates, Inc.

Dykstra, D. I., Boyle, C. F., \& Monarch, I. A. (1992). Studying conceptual change in learning physics. Science Education, 76(6), 615-652.

Engelhardt, P. V., \& Beichner, R. J. (2004). Students' understanding of direct current resistive electric circuits. American Journal of Physics, 72(1), 98-115.

Eryılmaz, A. (2010). Development and application of three-tier heat and temperature test: Sample of bachelor and graduate students. Eurasian Journal of Educational Research, 40, 53-76.

Göçen, G. \& Kabaran, H. (2013). Ortaöğretim 9. sınıf fizik dersi öğretim programlarının tarihsel süreç içerisinde karşılaştırmalı olarak incelenmesi [A comparative examination of the $9^{\text {th }}$ grade physics curricula in the historical period]. Fen Bilimleri Ögretimi Dergisi, 1(2), 147-157.

Hake, R. R. (1992). Socratic pedagogy in the introductory physics lab. The Physics Teacher, 30, 546-552.

Halloun, I., \& Hestenes, D. (1985a). The initial knowledge state of college physics students. American Journal of Physics, 53(11), 1043-1048.

Halloun, I., \& Hestenes, D. (1985b). Common sense concepts about motion. American Journal of Physics, 53(11), 1056-1065.

Halloun, I., \& Hestenes, D. (1998). Interpreting VASS dimensions and profiles for physics students. Science \& Education, 7(6), 553-577.

Hammer, D., \& Elby, A. (2003). Tapping epistemological resources for learning physics. The Journal of the Learning Science, 12, 53-90.

Heron, P. R. L., \& Meltzer, D. (2005). The future of physics education research: Intellectual challenges and practical concerns. American Journal of Physics, 73(5), 390-394.

Hestenes, D., \& Wells, M. (1992). A mechanics baseline test. The Physics Teacher, 30, 159-166.

Hestenes, D., Wells, M., \& Swackhamer, G. (1992). Force Concept Inventory. The Physics Teacher, 30, 141-158.

Hrepic, Z., Zollman, D. A., \& Rebello, N. S. (2010). Identifying students' mental models of sound propagation: The role of conceptual blending in understanding conceptual change. Physical Review Special Topics: Physics Education Research, 6(2), 020114 (1-18).

Hubber, P. (2006). Year 12 students' mental models of the nature of light. Research in Science Education, 36(4), 419-439.

Itza-Ortiz, S. F., Rebello, S., \& Zollman, D. (2004). Students' models of Newton's second law in mechanics and electromagnetism. European Journal of Physics, 25, 81-89.

İzci, K. (2014). Eleştirel araştırma. In M. Metin (Ed.), Kuramdan uygulamaya eğitimde bilimsel araştırma yöntemleri [Theoretical and practical scientific research methods in education] (pp.413-439). Ankara: Pegem A.

Kaltakci Gurel, D., Eryilmaz, A. \& McDermott, L. C. (2015). A Review and Comparison of Diagnostic Instruments to Identify Students' Misconceptions in Science. EURASIA Journal of Mathematics, Science and Technology Education, 11(5), 989-1008.

Kaltakci Gurel, D., Eryilmaz, A. \& McDermott, L. C. (2017). Development and application of a four-tier test to assess pre-service physics teachers' misconceptions about geometrical optics. Research in Science \& Technological Education, 35(2), 238-260. 
Kaltakçı Gürel, D. (2017). Bağlam (Yaşam) temelli fizik öğretimi uygulamaları ve REACT Stratejisi. In A. İ. Şen \& A. R. Akdeniz (Eds.), Fizik ögretimi-Kuramsal bilgiler ve örnek etkinlik uygulamalarl [Physics education: Theoretical explanations and implementation of sample activities] (pp. 357-382). Ankara: Pegem Akademi.

Kaltakçı-Gürel, D., Ölmeztürk, A., Durmaz, B., Abul, E., Özün, H., Irak, M., Subaşı, Ö., \& Baydar, Z. (2017a). 1990-2016 yılları arasında Türkiye'de fizik eğitimi alanında yapılmış lisansüstü tezlerin içerik analizi [The content analysis of the graduate theses in physics education in Turkey between the years 1990 and 2016]. Gazi Üniversitesi Gazi Eğitim Fakültesi Dergisi, 37 (3), 1141-1172.

Kaltakçı-Gürel, D., Sak, M., Ünal, Z. Ş., Özbek, V., Candaş, Z., \& Şen, S. (2017b). 1995-2015 yılları arasında Türkiye'de fizik eğitimine yönelik yayınlanan makalelerin içerik analizi [Content analysis of physics education articles published in Turkey between 1995 and 2015]. Mehmet Akif Ersoy Üniversitesi Eğitim Fakültesi Dergisi, 42, 143-167.

Kanlı, U., Gülçiçek, Ç., Göksu, V., Önder, N., Oktay, Ö., Eraslan, F., Eryılmaz, A., \& Güneş, B. (2014). Ulusal Fen Bilimleri ve Matematik Eğitimi Kongrelerindeki fizik eğitimi çalışmalarının içerik analizi [Content analysis of physics education studies published in national science and mathematics education congress proceedings]. Gazi Üniversitesi Gazi Ĕ̈itim Fakültesi Dergisi, 34 (2), 127-153.

Laws, P. (1991). Workshop physics: learning introductory physics by doing it. Change Magazine, 20-27.

Lee, M., Wu, Y., \& Tsai, C. (2009). Research trends in science education from 2003 to 2007: A content analysis of publications in selected journals. International Journal of Science Education, 31(15), 1999-2002.

Mazur, E. (1997). Peer instruction: a user's manual. Prentice-Hall: N.J.

McDermott, L. C. (1991). Millikan Lecture 1990: What we teach and what is learned-Closing the gap. American Journal of Physics, 59(4), 301-315.

McDermott, L. C. (1993). Guest comment: How we teach and how students learn a mismatch? American Journal of Physics, 61(4), 295-298.

McDermott, L. C. (1996). Physics by inquiry (Vols. 1 \& 2). Wiley: NY.

McDermott, L. C. (1997). Bridging the gap between teaching and learning: the role of research. In E. F. Redish \& J. S. Rigden (Eds.), International Conference on Undergraduate Physics Education: The changing role of physics departments in modern universities (pp. 139-165). Woodbury, NY: American Institute of Physics.

McDermott, L. C., \& Shaffer, P. (1998). Tutorials in introductory physics. Prentice Hall: NJ.

McDermott, L. C. (2012). A view from physics. (basımda)

Meltzer, D. E., \& Otero, V. K. (2015). A brief history of physics education in the United States. American Journal of Physics, 83(5), 447-458.

Önder, N., Oktay, Ö., Eraslan, F., Gülçiçek, Ç., Göksu, V., Kanlı, U., Eryılmaz, A., \& Güneş, B. (2013). Content analysis of physics education studies published in Turkish Science Education Journal from 2004 to 2011. Journal of Turkish Science Education, 10 (4), 151-163.

Özcan, Ö. (2015). Investigating students' mental models about the nature of light in different contexts. European Journal of Physics, 36(6),1-16.

Peşman, H., \& Eryılmaz, A. (2010). Development of a three-tier test to assess misconceptions about simple electric circuits. The Journal of Educational Research, 103, 208-222.

Rebello, N. S. \& Zollman, D. A. (2005). Trends in physics education research- a personal perspective. http://web.phys.ksu.edu/papers/2005/DZ_NSF_TrendsinPER.pdf adresinden alınmıştır.

Redish, E. F. (1994). Implications of cognitive studies for teaching physics. American Journal of Physics, 62(9), 796-803.

Redish, E. F., Saul, J. M., \& Steinberg, R. N. (1998). Student expectations in introductory physics. American Journal of Physics, 66(3), 212-224. 
Redish, E. F., \& Steinberg, R. N. (1999). Teaching physics: Figuring out what works. Physics Today, 52, $24-30$.

Reif, F. (1995). Millikan Lecture 1994: Understanding and teaching important scientific thought processes. American Journal of Physics, 63(1), 17-32.

Reif, F. (1997). How can we help students acquire effectively usable physics knowledge? In E. F. Redish \& J. S. Rigden (Eds.), International Conference on Undergraduate Physics Education: The changing role of physics departments in modern universities (pp. 179-195). Woodbury, NY: American Institute of Physics.

Sokolof, D.R. \& Thornton, R. K. (1997). Using interactive lecture demonstrations to create an active learning environment. The Physics Teacher, 35(9), 340-347.

Sokoloff, D.R., Thornton, R. K., \& Laws, P. W. (1999). RealTime physics: active learning laboratories. Wiley \& Sons: NJ.

Sözbilir, M. ve Canpolat, N. (2006). Fen eğitiminde son otuz yıldaki uluslararası değişimler: Dünyada çalışmalar nereye gidiyor? Türkiye bu çalışmaların neresinde? In M. Bahar (Ed.), Fen ve teknoloji öğretimi (1. baskı) [Science and technology education (1st ed.)] (pp. 417-432). Ankara: Pegem.

Taşlıdere, E. \& Eryılmaz, A. (2012). Basit elektrik devreleri konusuna yönelik tutum ölçeği geliştirilmesi ve öğrencilerin tutumlarının değerlendirilmesi [Development of an attitude scale about the simple electric circuits and the evaluation of students' attitudes]. Türk Fen Eğitimi Dergisi, 9(1), 31-46.

Thornton, R. K., \& Sokoloff, D. R. (1998). Assessing student learning of Newton's Laws: The force and motion conceptual evaluation and the evaluation of active learning laboratory and lecture curricula. American Journal of Physics, 66(4), 338-352.

Tongchai, A., Sharma, M. D., Johnston, I. D., Arayathanitkul, K., \& Soankwan, C. (2009). Developing, evaluating and demonstrating the use of a conceptual survey in mechanical waves. International Journal of Science Education, 31(18), 2437-2457.

Tsai, C., \& Wen, M. L. (2005). Research and trends in science education from 1998 to 2002: A content analysis of publication in selected journals. International Journal of Science Education, 27(1), 3-14.

Tzu-Chiang, L., Tzung-Jin, 1., \& Chin-Chung, T. (2014). Research trends in science education from 2008 to 2012 : A systematic content analysis of publications in selected journals. International Journal of Science Education, 36(8), 1346-1372.

Vygotsky, L. S. (1978). Mind in society: The development of higher psychological processes. Cambridge M. A.: Harvard University Press.

Yerdelen-Damar, S., Elby, A. \& Eryılmaz, A. (2012). Applying beliefs and resources frameworks to the psychometric analyses of an epistemology survey. Physical Review Physics Education Research, 8, 010104$1-10$.

Wells, M., Hestenes, D., \& Swackhamer, G. (1995). A modeling method for high school physics instruction. American Journal of Physics, 63, 606-619.

Wilson, J. M. (1994). The CUPLE physics studio. The Physics Teacher, 32, 518-523.

White, B., Andrew, E., Frederiksen, J., \& Schwarz, C. (1999). The Epistemological Beliefs Assessment for Physical Science. American Education Research Association (AERA) Konferansında sunulmuştur, Montreal.

Wittmann, M. C., Steinberg, R. N., \& Redish, E. F. (1999). Making sense of how students make sense of mechanical waves. The Physics Teacher, 37(1), 15-21. 